\title{
Trends in the development of turbocharging systems in automotive vehicles
}

\begin{abstract}
The application of turbocharging systems results in serious problems related to the delivery of appropriate amount of air needed to entirely burn the supplied dose of fuel. This problem is particularly relevant for non-adjustable turbocharging systems (constant geometry turbines). The improvements of the turbocharging systems in compression ignition engines may be implemented through such solutions as two stage or sequential turbocharging that show significant benefits as opposed to a single stage variable turbocharger geometry (VGT) turbocharging. The paper presents adjustable two stage turbocharging and sequential turbocharging finding application in serially manufactured vehicles. The assessment of the properties of these solutions and attempts to describe the trends in the further development of the turbocharging systems have been made. With this background, the results of own research of the author have been presented performed on a SW 680 sequentially turbocharged engine.
\end{abstract}

Key words: CI engine, turbocharging, two stage turbocharging, sequential turbocharging

\section{Kierunki rozwoju systemów turbodoładowania silników samochodowych}

\begin{abstract}
Z zastosowaniem turbodoładowania wiqża się istotne problemy wynikajace $w$ głównej mierze z możliwości doprowadzenia odpowiedniej ilości powietrza potrzebnej do całkowitego spalenia dawki paliwa. Problem ten jest szczególnie istotny w układach bez regulacji doładowania. Poprawie parametrów pracy turbodoładowanych silników o zapłonie samoczynnym moga stużyć takie rozwiqzania, jak doładowanie dwustopniowe lub doładowanie zakresowe, które wykazują istotne korzyści także w stosunku do doładowania jednostopniowego turbosprężarkq o zmiennym kqcie nachylenia topatek kierownicy turbiny VTG. W artykule przedstawiono rozwiazania regulowanego doładowania dwustopniowego oraz doładowania zakresowego, które znalazty zastosowanie w seryjnie produkowanych samochodach. Dokonano oceny właściwości tych rozwiqzań i próby nakreślenia kierunków dalszego rozwoju systemów turbodoładowania. Na tym tle przedstawiono wyniki badań własnych autora, prowadzone na silniku SW 680 z doładowaniem zakresowym.
\end{abstract}

Słowa kluczowe: silnik ZS, turbodoładowanie, doładowanie dwustopniowe, doładowanie zakresowe

\section{Introduction}

The development works conducted within the last two decades resulted in diesel engines approximating gasoline engines in terms of performance parameters with the fuel economy of the former remaining on a lower level. One of the factors conducive to the improvement of diesel engines was the overcoming of the problems related to the realization of high pressure injection as well as the popularization of intercooled turbocharing. Lower fuel consumption, lower emissions and better dynamics (approximating that of gasoline engines) ensued, particularly in modern direct injection engines. Turbocharging does generate certain problems related to the delivery of appropriate amount of air needed to entirely burn the supplied dose of fuel. This is related to the delay in the air supply by the turbocharger not only during sudden acceleration but also at steady state engine work conditions. The problem is particularly valid in non-adjustable turbocharging systems, where the turbocharger is calibrated to the nominal conditions. The required charging pressures are obtained only when the nominal power is reached. In order to ensure the optimum turbocharging efficiency adjustable turbocharging systems are necessary.

\section{Description of the problem}

Now that the VTG trubochargers have an established position in the market as a solution popularly applied in

\section{Wstęp}

Prowadzone w ostatnich dwóch dekadach prace rozwojowe spowodowały, że silniki o zapłonie samoczynnym (ZS) zbliżyły się pod względem osiągów do silników o zapłonie iskrowym (ZI), przy wciąż znacznie mniejszym zużyciu paliwa. Jednym z czynników sprzyjających rozwojowi silników o ZS było opanowanie problemów związanych z realizacją wysokociśnieniowego wtrysku, a także upowszechnienie turbodoładowania $\mathrm{z}$ jednoczesnym chłodzeniem powietrza doładowującego. Uzyskano dzięki temu zmniejszenie zużycia paliwa i zmniejszenie emisji związków toksycznych, zwłaszcza w nowoczesnych jednostkach $\mathrm{z}$ wtryskiem bezpośrednim, oraz dynamikę porównywalną z silnikami o ZI. Z zastosowaniem turbodoładowania wiążą się pewne problemy wynikające w głównej mierze z możliwości doprowadzenia odpowiedniej ilości powietrza potrzebnej do całkowitego spalenia dawki paliwa. Dotyczy to nie tylko wystepowania niekorzystnego zjawiska zwłoki w podawaniu powietrza przez sprężarkę podczas gwałtownego przyspieszania, lecz również ustalonych warunków pracy silnika. Problem ten jest szczególnie istotny w układach bez regulacji ciśnienia doładowania, w których turbosprężarka musi być dopasowana do warunków znamionowych. Wymagane ciśnienia doładowania uzyskiwane są dopiero przy mocy znamionowej. Do zapewnienia odpowiedniej wydajności turbodoładowania konieczne jest zastosowanie układów regulacji. 
passenger car and light duty truck diesel engines, certain limits in a single stage turbocharging became visible. In currently designed single stage turbochargers the compression rate limit is 4 and one should not expect this value to grow due to a considerable drop in the efficiency. Besides, a higher nominal power rating usually leads to a lowering of the engine torque at lower engine speeds. Fig. 1a presents a flow characteristics of a turbocharger with an added line of cooperation with the engine. In a single stage turbocharging the full characteristics of the turbocharger is utilized including areas where the efficiency of the charger is low. The points of work of the engine may significantly vary from the line of its maximum efficiency. The pumping limit of a turbocharger at low flow intensity reduces the possibility of obtaining the required compression rate at lower engine speed as well. This problem intensifies with the growth of the nominal power and extension of the usable speed range of an engine, which forces a use of chargers of characteristics covering a wide range of air delivery rate and a flat pumping limit. The increase in the charging pressure at low

a)

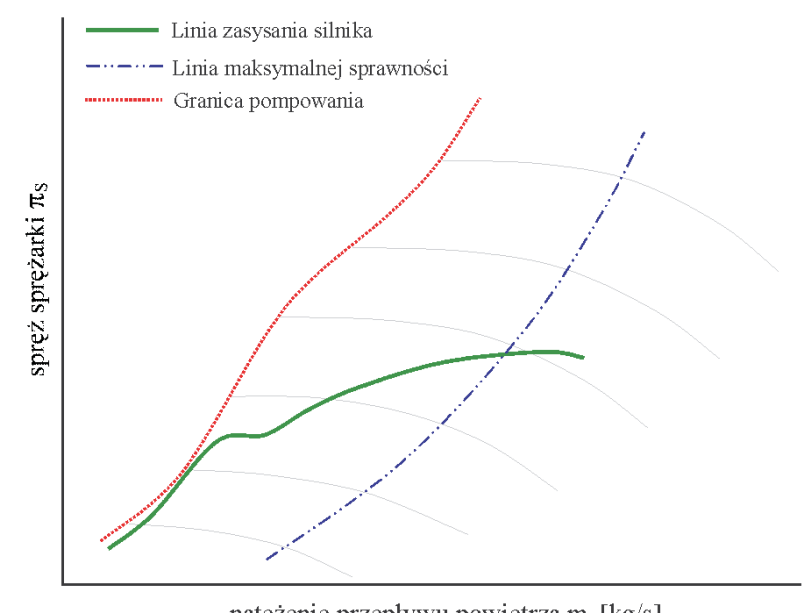

\section{Opis problemu}

Obecnie, gdy turbosprężarki typu VTG utrwaliły swoją pozycje jako rozwiązanie powszechnie stosowane w silnikach o ZS przeznaczonych do samochodów osobowych oraz częściowo do samochodów dostawczych, uwidoczniły się jednocześnie granice doładowania jednostopniowego. W obecnie budowanych jednostopniowych turbosprężarkach osiągane są wartości sprężu 4 i nie należy oczekiwać dalszego wzrostu ciśnienia doładowania w układzie jednostopniowym ze względu na nieunikniony znaczny spadek sprawności. Ponadto, większa moc znamionowa prowadzi najczęściej do zmniejszenia wartości momentu obrotowego silnika w zakresie mniejszej prędkości obrotowej. Na rysunku 1a przedstawiona została charakterystyka przepływowa sprężarki z naniesioną linią współpracy z silnikiem. Przy doładowaniu jednostopniowym wykorzystana jest cała charakterystyka sprężarki, obejmująca również obszary, gdzie sprawność sprężania jest bardzo mała. Punkty pracy silnika mogą znacznie odbiegać od linii jej maksymalnej sprawności. Również sam przebieg granicy pompowania

b)

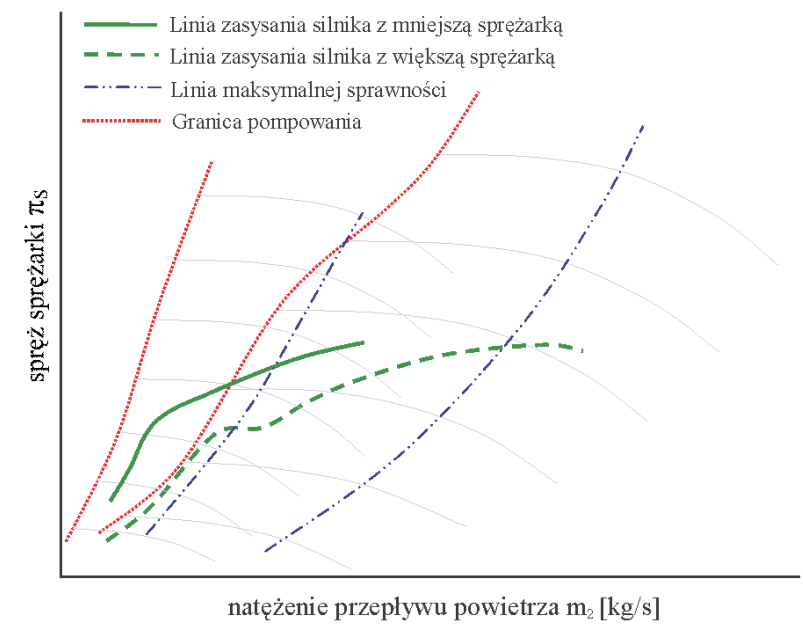

Fig. 1. Possibilities of use of the turbocharger characteristics in the engine - charger cooperation: a) smaller, b) larger Rys. 1. Możliwości wykorzystania charakterystyki sprężarki przy wspólpracy silnika z turbosprężarka: a) większa, b) mniejszq

engine speed requires the application of turbochargers of a steep pumping limit, characterized by a lower air delivery rate. Hence, it is possible in engines of a narrow range of usable engine speeds and moderate charging rates. Such a situation is shown in Fig. 1b, where, for comparison, lines of cooperation with the engine have been shown (smaller and larger turbocharger).

Further improvements of the operation of turbocharged diesel engines may be implemented through such solution as two stage or sequential turbocharging. These systems show significant advantages as opposed to a single stage VTG turbocharging before the limit (drop in efficiency) is reached. sprężarki przy niewielkich natężeniach przepływu powietrza ogranicza możliwości uzyskania wymaganych wartości sprężu w zakresie mniejszej prędkości obrotowej silnika. Problem ten nasila się wraz ze wzrostem mocy znamionowej oraz rozszerzeniem użytecznego zakresu prędkości obrotowej silnika, co zmusza do stosowania sprężarek o charakterystykach obejmujących szeroki zakres wydatków powietrza i o płasko przebiegającej granicy pompowania. Zwiększenie ciśnienia doładowania przy małej prędkości obrotowej wymaga zastosowania mniejszych sprężarek o stromo przebiegającej granicy pompowania, które charakteryzują się jednak mniejszym wydatkiem powietrza. Jest więc to możliwe w silnikach o wąskim zakresie użytecznych prędkości obrotowych i umiarkowanych wartościach stopnia 


\section{Multistage turbocharging systems}

In a multistage turbocharging system $[1,3,9,27]$ the smaller, high pressure turbocharger (1) and the larger low pressure turbocharger (2) are in a serial configuration (Fig. 2a). This gives way to intercooling. It is an important advantage of this system. Thanks to this solution, to a large extent, the disadvantageous value of the total efficiency occurring in a two stage system can be compensated, because, beginning at a certain power value, even at optimum configuration of the turbochargers the obtained efficiencies are not high. In two stage turbocharging the division of pressure drops between the stages is particularly important for which an optimum must be sought. The division of power between both stages of the compressor and the turbine is important not only in terms of the total system efficiency but also in terms of the design and properties of the turbochargers. Attention must be paid to the pumping limit of the chargers. On the characteristics of the larger, low pressure compressor the pumping limit is more flat than it is in the case of the smaller, high pressure compressor. This may cause the risk of reaching the pumping limit by the larger compressor while, at growing loads, the low pressure compressor power share is too low. This may also generate problems while operating at part loads. To this end, it is purposeful to aim at high power share of the low pressure compressor $[2,3]$. The application of the bypass valve (4) (waste-gate) allows and adjustment of the power share of the two turbochargers and leads to the improvement of the dynamic properties. These solutions are applied in large engines of heavy duty vehicles. However, the application of such a solution in passenger cars requires certain modifications (Fig. 2b) consisting in a fitting of a valve (5) in the bypass channel of the high pressure turbocharger. This

a)

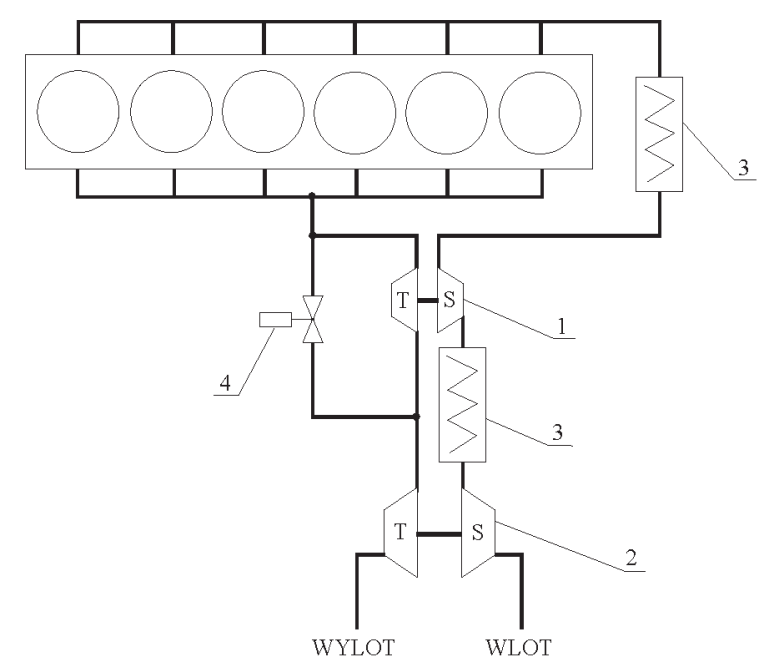

doładowania. Sytuację taką ilustruje rys. 1b, na którym dla porównania przedstawione zostały możliwe do uzyskania linie współpracy z silnikiem mniejszej i większej sprężarki.

Dalszej poprawie parametrów pracy turbodoładowanych silników ZS mogą służyć takie rozwiązania, jak np. doładowanie dwustopniowe lub doładowanie sekwencyjne. Systemy te wykazują istotne korzyści także w stosunku do doładowania jednostopniowego turbosprężarką VGT, zanim osiagnie się granicę charakteryzującą się spadkiem sprawności.

\section{Systemy doładowania wielostopniowego}

W doładowaniu wielostopniowym $[1,3,9,27]$ mniejsza sprężarka stopnia wysokiego ciśnienia (1) oraz większa niskociśnieniowa (2) połączone są szeregowo (rys. 2a). Stwarza to możliwość zastosowania chłodzenia międzystopniowego. Jest to istotną zaletą takiego układu. Dzięki temu w dużej mierze może być kompensowana niekorzystna wartość sprawności całkowitej, występująca w układzie dwustopniowym, gdy począwszy od określonej mocy, nawet przy optymalnym dopasowaniu turbosprężarek, osiagane sprawności nie są wysokie. Przy dwustopniowym doładowaniu szczególnie ważny jest podział spadków ciśnień pomiędzy stopniami niskiego i wysokiego ciśnienia, dla którego należy znaleźć optimum. Podział mocy między oba stopnie sprężarkowe oraz turbinowe jest ważny nie tylko z uwagi na całkowitą sprawność układu, ale również ze względu na budowę i właściwości turbosprężarek. Szczególną uwagę należy zwrócić na granicę pompowania sprężarek. Na charakterystyce większej sprężarki stopnia niskiego ciśnienia granica pompowania przebiega bardziej płasko niż na charakterystyce mniejszej sprężarki stopnia

b)

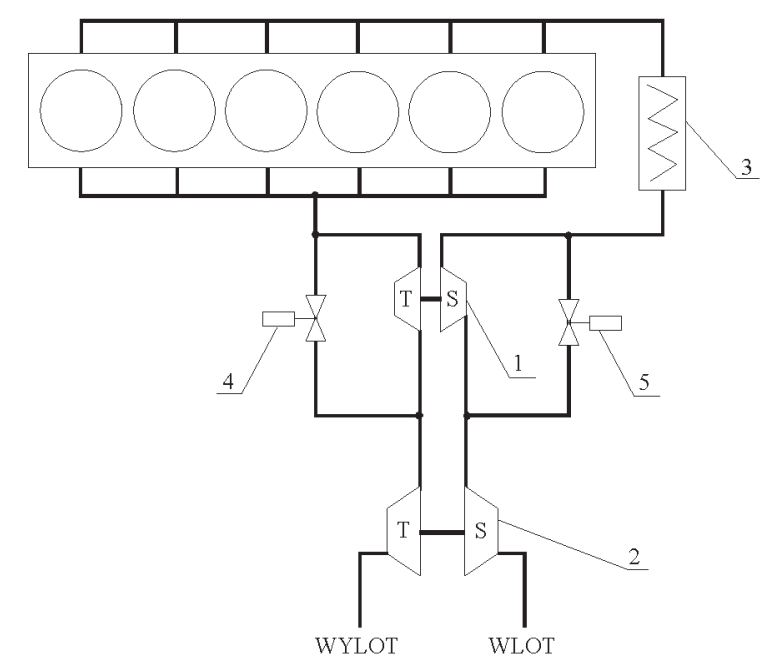

Fig. 2. A two stage charging system: a - with a bypass channel for heavy duty vehicles, b - with a bypass channel of the compressor and the turbine for passenger vehicles: 1 - high pressure turbocharger, 2 - low pressure turbocharger, 3 - intercooler, 4 - valve in the bypass channel of a high pressure turbine, 5 - valve in the bypass channel of a high pressure compressor

Rys. 2. System dwustopniowego doładowania: a - z kanałem obejściowym turbiny dla silników samochodów użytkowych, b-z kanałem obejściowym sprężarki i turbiny dla silników samochodów osobowych: 1 - turbosprężarka wysokociśnieniowa, 2 - turbosprężarka niskociśnieniowa, 3 - chłodnica powietrza, 4 -zawór w kanale obejściowym turbiny stopnia wysokiego ciśnienia, 5 - zawór w kanale obejściowym sprężarki stopnia wysokiego ciśnienia 
results from a much broader range of usable engine speeds in passenger vehicles. The application of this bypass channel allows an adjustment of the charging parameters in a much broader range, protecting the engine from an excessive charging pressure under nominal conditions. Alternatively to the waste gate solution in the bypass channel of a high pressure compressor (5) a VTG turbocharger [8, 23] can be applied.

Recently, in serial passenger diesel vehicles such systems of two stage adjustable turbocharging similar in design to the heavy duty solution, have been applied. The technology goes by the name of Twin-Turbo. These solutions utilize two turbochargers of different size operating in a serial configuration but at some engine speed ranges they change configuration to parallel with the option of a full bypass of either of them.

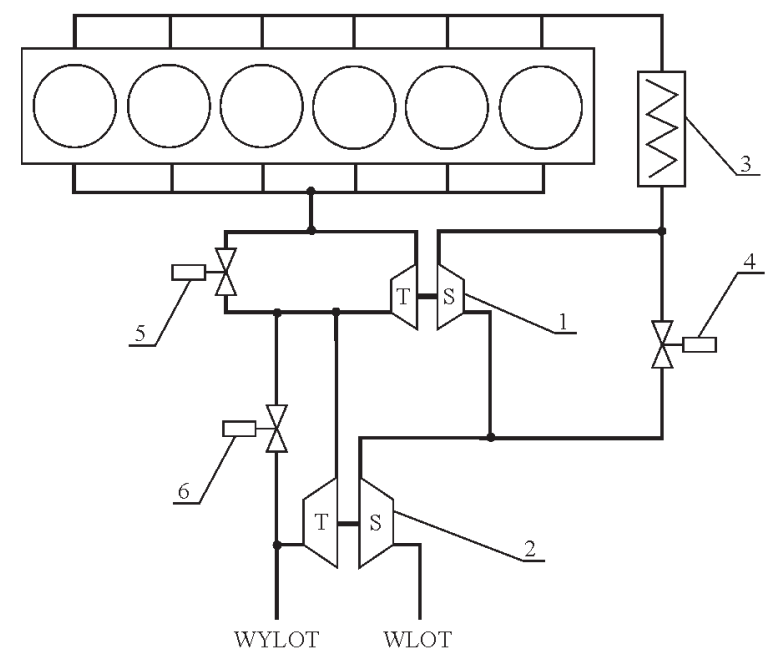

Fig. 3. Schematics of an adjustable two stage turbocharging system in a BMW engine: 1 - small turbocharger, 2 - large turbocharger, 3 - intercooler, 4 - valve in the bypass channel of the small compressor, 5 - valve in the bypass channel of the small turbine, 6 - wastegate of the larger turbine

Rys. 3. Schemat działania układu regulowanego doładowania dwustopniowego w silniku BMW: 1 - mała turbosprężarka, 2 -duża turbosprężarka, 3 -chłodnica powietrza doładowanego, 4-zawór w kanale obejściowym mniejszej sprężarki, 5-zawór w kanale obejściowym mniejszej turbiny, 6-zawór upustowy spalin większej turbiny

The turbocharging system developed by BMW goes by the name of Variable Twin-Turbo (VTT). The schematics of the system with three electronically controlled valves fitted in the intake and exhaust manifolds is shown in Fig. 3. This solution allows increasing of the charging pressure at nominal engine speed and improves the engine performance at low revolutions. Thanks to the turbochargers of different size, the smaller, high pressure turbocharger (1) enables the system to promptly react to abrupt changes of load while the larger, low pressure turbocharger (2) ensures high nominal power. In the mid range of engine revolutions the turbochargers operate in a serial configuration, which allows high levels of mean effective pressure. Figure 5 shows different areas of work of the VVT on a general characteristics of the engine. In the lowest range of the engine revolutions and load (area 1) all the control valves are closed. The air flows through wysokiego ciśnienia. Może to powodować znaczne niebezpieczeństwo osiagnięcia granicy pompowania podczas pracy większej sprężarki, gdy przy wzrastającym obciążeniu udział mocy stopnia niskiego ciśnienia będzie zbyt mały. Może to również stwarzać problemy podczas pracy przy obciążeniach częściowych. $Z$ tego powodu celowe jest dążenie do możliwie dużego udziału mocy stopnia niskiego ciśnienia $[2,3]$. Zastosowanie zaworu w kanale obejściowym spalin (4) typu waste-gate pozwala na regulację stopnia podziału mocy tych dwóch turbosprężarek oraz prowadzi do poprawy właściwości dynamicznych. Tego typu układy są stosowane w dużych silnikach samochodów użytkowych. Natomiast wykorzystanie takiego układu w silniku samochodu osobowego (rys. 2b) wymaga pewnej modyfikacji, która polega na zastosowaniu zaworu (5) w kanale obejściowym sprężarki stopnia wysokociśnieniowego. Wynika to ze znacznie szerszych zakresów użytecznych prędkości obrotowych silników przeznaczonych do samochodów osobowych. Zastosowanie tego kanału obejściowego pozwala w znacznie szerszym zakresie regulować parametry doładowania, zabezpieczając jednocześnie silnik przed nadmiernym wzrostem ciśnienia doładowania w warunkach znamionowych. Alternatywnie, do regulacji mocy stopnia wysokiego ciśnienia zamiast zaworu typu waste-gate (5) w kanale obejściowym turbiny możliwe jest zastosowanie turbosprężarki typu VTG [8, 23].

Ostatnio w seryjnie wytwarzanych samochodach osobowych z silnikami ZS zastosowano tego typu systemy regulowanego doładowania dwustopniowego, bardzo zbliżone konstrukcyjnie i określane terminem Twin-Turbo. Rozwiązania te wykorzystują dwie turbosprężarki różnej wielkości połączone szeregowo, lecz pracujące w pewnym zakresie prędkości obrotowych silnika również w układzie równoległym z możliwością odłączenia jednej z nich.

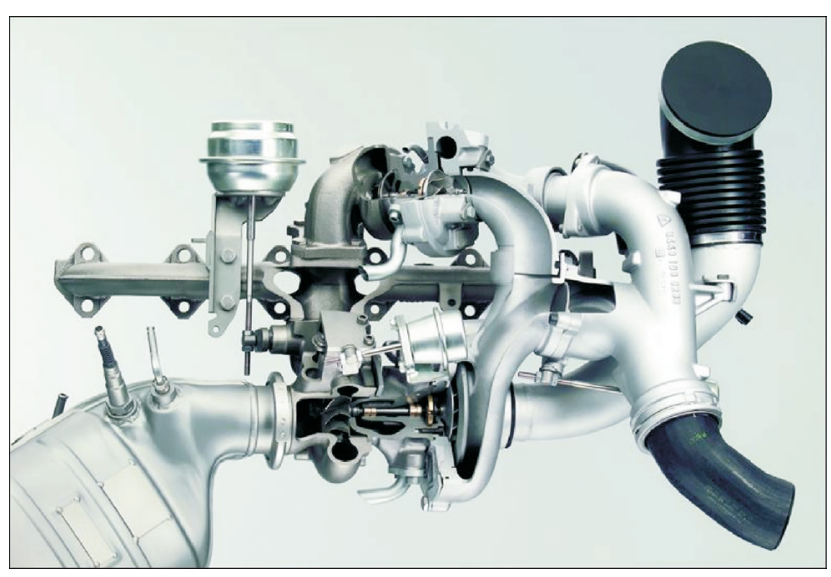

Fig. 4. Adjustable two stage turbocharging system in a six cylinder in line BMW diesel engine R6D, $3 \mathrm{dm}^{3}$ capacity and $200 \mathrm{~kW}$ [30] power rating

Rys. 4. Układ regulowanego doładowania dwustopniowego sześciocylindrowego rzędowego silnika BMW R6D o ZS o objętości skokowej $3 \mathrm{dm}^{3} \mathrm{i}$ mocy $200 \mathrm{~kW}[30]$

System doładowania zrealizowany przez BMW określany jest terminem Variable Twin-Turbo (VTT). Schemat układu ze sterowanymi elektronicznie trzema zaworami 
the large turbocharger first and then through the small one which at that time generates the charging pressure. Thanks to the initial compression of the medium by the larger turbocharger (areas 1,2) the compression work of the smaller turbocharger is reduced. From the exhaust side the exhaust is directed towards the turbine of the smaller turbocharger, which ensures a faster growth of the charging pressure. On reaching of the desired charging pressure valve (5) opens in the bypass channel of the smaller turbine and a part of the exhaust gas is directed towards the large turbine. The opening of the valve (5) is smoothly adjusted by the engine control unit depending on the engine speed and load. This allows adjusting the charging pressure. Valve (4) in the bypass channel of the compressor remains closed. When the engine speed grows, the air flow is choked, the pressure generated by the small compressor cannot grow and valve (4) opens. The switching of valve (4) is realized stepwise until the full opening position and is synchronized with the maximum opening of the bypass channel of the turbine. This occurs depending on the load from approximately $30001 / \mathrm{min}$ (area 3 ). In this area at the valves in a fully open position (4), (5) the exhaust is entirely directed towards the turbine of the large turbocharger which generates the required charging pressure. This ensures the obtaining of the nominal power rating. The charging pressure of the large turbocharger is adjusted by the wastegate valve (6) (area 4). The synchronization of the valve switching in the bypass channels of the compressor and the turbine allows the compensation of the influence of the changes in the compression efficiency on the course of the engine torque. During the switching to the large turbocharger which is adapted for large air and exhaust flow intensities, the efficiency of the compressor and the turbine grows significantly. Hence, in order to avoid a stepwise change of the torque in the initial phase of the switching, a reduction of the fuel dose is necessary. In this way, the switching is unnoticeable for the driver [28].

This system was successfully tested in the engine of a performance version of a BMW passenger car - BMW X5 during the Dakar Rally in 2004. It was subsequently fitted in a six cylinder diesel engine in BMW 1.3 and 5 series. The development potential of diesel engines with two stage adjustable charging systems lies in the high unitary power, which in this class of engines is on average $20 \%$ higher than in other modern diesel engines. The six cylinder engine 535d 3.0 R6D, fitted in BMW has the power of $200 \mathrm{~kW}$ at $4400 \mathrm{1} / \mathrm{min}$. This corresponds to the unitary power of 67 $\mathrm{kW} / \mathrm{dm}^{3}$. The maximum torque amounts to 560 umieszczonymi w układzie dolotowym i wylotowym silnika przedstawia rys. 3. Rozwiązanie to daje możliwości zwiększenia ciśnienia doładowania przy obrotach znamionowych, a jednocześnie znacznie poprawia osiagi silnika w zakresie małej prędkości obrotowej. Dzięki zastosowaniu turbosprężarek różnej wielkości mniejsza turbosprężarka stopnia wysokiego ciśnienia (1) umożliwia szybką reakcję na gwałtowne zmiany obciążenia, podczas gdy większa turbosprężarka stopnia niskiego ciśnienia (2) zapewnia dużą moc znamionową. W średnim zakresie prędkości obrotowych sprężarki działają w układzie szeregowym, co zapewnia duże wartości średniego ciśnienia użytecznego. Rysunek 5 przedstawia różne obszary pracy układu VTT na charakterystyce ogólnej silnika. W najniższym zakresie prędkości obrotowej i obciążenia (obszar 1) wszystkie zawory sterujące pozostają zamknięte. Powietrze najpierw przepływa przez dużą, a następnie przez małą sprężarkę, która w tym okresie wytwarza ciśnienie doładowania. Dzięki wstępnemu sprężeniu czynnika przez większą sprężarkę (obszary 1,2) zmniejsza się praca sprężania mniejszej sprężarki. Od strony wylotowej spaliny są kierowane najpierw na turbinę mniejszej turbosprężarki, co zapewnia szybszy wzrost ciśnienia doładowania. Po osiągnięciu zadanego ciśnienia doładowania otwiera się zawór (5) w kanale obejściowym mniejszej turbiny i część spalin kierowana jest na dużą turbinę. Stopień otwarcia zaworu (5) jest płynnie regulowany w zależności od prędkości obrotowej i obciążenia przez sterownik silnika. Pozwala to regulować ciśnienie doładowania. Zawór (4) w kanale obejściowym sprężarki pozostaje zamknięty. Gdy przy zwiększaniu prędkości obrotowej, ze względu na dławienie przepływu powietrza, ciśnienie wytwarzane przez małą sprężarkę nie będzie mogło wzrastać, otwiera się zawór (4). Przełączenie zaworu (4) realizowane jest skokowo do położenia maksymalnego otwarcia i jest zsynchronizowane z maksymalnym otwarciem kanału obejściowego turbiny. Następuje to w zależności od obciążenia od ok. 3000 $1 /$ min (obszar 3). W tym obszarze przy całkowicie otwartych zaworach (4), (5) spaliny w całości kierowane są na turbinę dużej turbosprężarki, która wytwarza wymagane ciśnienie doładowania. Zapewnia to uzyskanie mocy znamionowej.

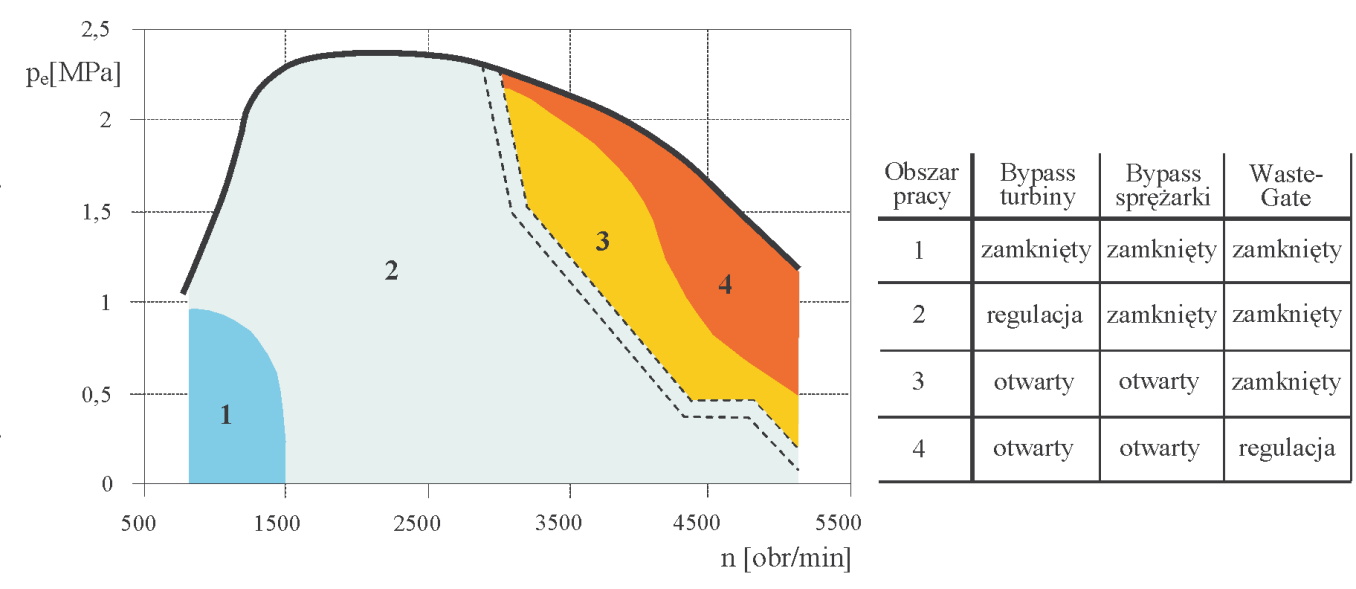

Fig. 5. Areas of work of the two stage adjustable charging system on a general characteristics of a BMW engine Rys. 5. Obszary pracy układu regulowanego doładowania dwustopniowego na charakterystyce ogólnej silnika BMW 
$\mathrm{N} \cdot \mathrm{m}$ at $20001 / \mathrm{min}$. The improvement of the performance is combined with the reduction of toxic emissions, thus, the engine complies with the Euro 4 standard and the fuel consumption amounts to $8 \mathrm{dm}^{3} / 100 \mathrm{~km}$ [23]. For comparison, in a standard engine fitted in BMW 530d turbocharged by a VTG the maximum torque amounts to $500 \mathrm{~N} \cdot \mathrm{m}$, and the nominal power is $150 \mathrm{~kW}$ at $40001 / \mathrm{min}$, which corresponds to a unitary power of $50 \mathrm{~kW} / \mathrm{dm}^{3}$.

In a system developed by Opel, similarly to BMW, two turbochargers of different size were applied [22]. The difference between the BMW and Opel engines is that in the Opel system there are two intercoolers downstream each of the compressors, and in the bypass channel of a high pressure compressor, instead of the pneumatically actuated valve, a one way return valve is fitted. At low engine speed below $18001 /$ min the valve in the bypass channel of the smaller, high pressure turbine remains closed and the whole exhaust mass is first directed towards the small and then the large low pressure turbocharger. The sucked air is initially compressed by the larger turbocharger and is subsequently cooled down. When the one way return valve is closed, the whole air stream flows through the smaller compressor where it is additionally compressed and cooled. When the engine speed exceeds 1800 $1 / \mathrm{min}$, as the turbine actuating valve is being opened in the bypass channel of the smaller turbine, the amount of exhaust flowing directly through the large turbocharger grows and decreases for the small one. For high engine speeds, above $3000 \mathrm{1} / \mathrm{min}$ due to the operating pressure equalization of both compressors, the one direction return valve is opened. A full opening of the valve in the bypass channel of the smaller turbine occurs as well. As a result only a miniscule amount of medium flows through the small turbine and the charging is realized through the larger turbocharger. This system was applied in a diesel direct injection common rail engine of a capacity of $1.9 \mathrm{dm}^{3}$ identified as Ecotec CDTI, known from Opel Vectra. Its nominal power amounts to $156 \mathrm{~kW}, 50 \%$ higher than its basic version, still maintaining the stringent

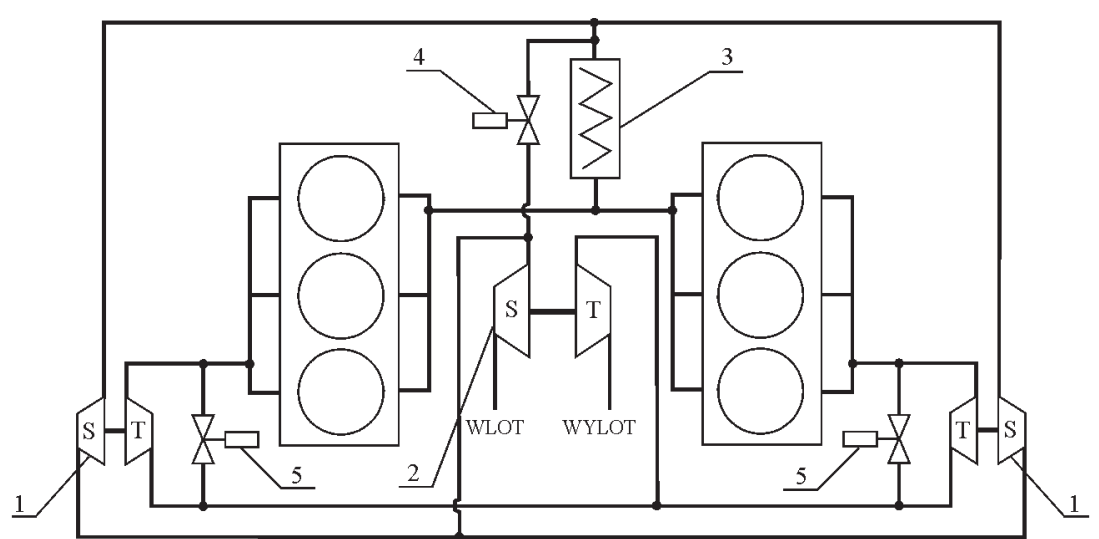

Fig. 6. Schematics of a two stage adjustable turbocharging systems in a v-type engine: 1 - high pressure compressor, 2 - low pressure compressor, 3 -intercooler, 4 - valve in the bypass channel of the smaller compressor, 5 - valve in the bypass channel of the smaller turbine

Rys. 6. Schemat uktadu regulowanego doładowania dwustopniowego $w$ silniku widlastym:

1 - turbosprężarka wysokociśnieniowa, 2 -turbosprężarka niskociśnieniowa, 3 - chłodnica powietrza, 4-zawór w kanale obejściowym mniejszych sprężarek, 5-zawór w kanale obejściowym mniejszej turbiny
Ciśnienie doładowania dużej turbosprężarki regulowane jest przez zawór upustowy spalin (6) (obszar 4). Synchronizacja przełączania zaworów w kanałach obejściowych sprężarki oraz turbiny pozwala kompensować wpływ zmian sprawności sprężania na przebieg momentu obrotowego silnika. Podczas przełączania na dużą turbosprężarkę, która jest dopasowana do dużych natężeń przepływu powietrza i spalin, wyraźnie wzrasta sprawność sprężarki oraz turbiny. Dlatego, aby uniknąć skokowej zmiany momentu obrotowego w pierwszej fazie przełączania, konieczna jest redukcja dawki wtrysku paliwa. Dzięki temu proces przełączania następuje w sposób zupełnie niezauważalny dla kierowcy [28].

Układ ten sprawdzony został z powodzeniem w silniku wyczynowej wersji BMW X5 podczas Rajdu Dakar w 2004 r., a następnie zastosowany $\mathrm{w}$ sześciocylindrowym silniku o ZS, znanym m.in. z modeli serii 1, 3, 5. O potencjale rozwojowym silników ZS z technologią regulowanego dwustopniowego doładowania świadczy wysoka moc jednostkowa, która w tej klasie silników jest średnio o 20\% wyższa, niż w przypadku innych nowoczesnych silników ZS. Montowany w modelu BMW 535d sześciocylindrowy silnik 3.0 R6D rozwija moc znamionową $200 \mathrm{~kW}$ przy 4400 1/min. Odpowiada to mocy jednostkowej $67 \mathrm{~kW} / \mathrm{dm}^{3}$. Natomiast maksymalny moment obrotowy $560 \mathrm{~N} \cdot \mathrm{m}$ rozwijany jest już przy 2000 1/min. Poprawa właściwości użytkowych połączona jest ze zmniejszeniem emisji toksycznych składników spalin, dzięki czemu możliwe jest spełnienie norm EURO 4, a zużycie paliwa wynosi ok. $8 \mathrm{dm}^{3} / 100 \mathrm{~km} \mathrm{[23].}$ Dla porównania, w standardowym silniku modelu BMW 530d doładowanym turbosprężarką typu VTG maksymalny moment obrotowy wynosił $500 \mathrm{~N} \cdot \mathrm{m}$, a moc znamionowa $150 \mathrm{~kW}$ rozwijana przy $4000 \mathrm{1} / \mathrm{min}$, co odpowiada mocy jednostkowej $50 \mathrm{~kW} / \mathrm{dm}^{3}$.

W układzie opracowanym przez firmę Opel, podobnie jak w BMW, zastosowane zostały dwie turbosprężarki o różnej wielkości [22]. Natomiast w odróżnieniu od rozwiązania BMW występują dwie chłodnice powietrza doładowanego umieszczone za każdą sprężarką, a w kanale obejściowym sprężarki stopnia wysokiego ciśnienia zamiast zaworu uruchamianego siłownikiem pneumatycznym umieszczony został samoczynny jednokierunkowy zawór zwrotny. Przy małej prędkości obrotowej silnika poniżej 1800 1/min zawór w kanale obejściowym mniejszej turbiny stopnia wysokiego ciśnienia pozostaje zamknięty i cała masa spalin kierowana jest najpierw na napęd małej, a następnie większej turbosprężarki stopnia niskiego ciśnienia. Zasysane powietrze jest wstępnie sprężone przez większą turbosprężarkę, a następnie ulega schłodzeniu. Przy zamkniętym jednokierunkowym zaworze zwrotnym cały strumień powietrza przepływa przez mniejszą sprężarkę, gdzie ulega dodatkowemu sprężeniu i ponownemu schłodzeniu. Przy wzroście prędkości 
Euro 4 exhaust emission standards. The maximum torque $400 \mathrm{~N} \cdot \mathrm{m}$ is obtained in the range from 1400 through 3500 $1 / \mathrm{min}[17]$. The values of mean effective pressure $2.6 \mathrm{MPa}$ and unitary power $82 \mathrm{~kW} / \mathrm{dm}^{3}$ for automotive vehicles are currently judged as all time high.

Special solutions of this systems have been developed for v-type engines. These solutions use two or three turbochargers [28]. In the first case both turbochargers may be fitted between the lines of cylinders and in the second case - the smaller high pressure turbochargers are fixed directly to the exhaust manifold and the joint low pressure turbocharger is located between the lines of the cylinders. A schematics of such a solution has been shown in Fig. 6. The system involving three turbochargers known as Tri-turbo, was fitted in a 2005 prototype version of a Mercedes-Benz SLK 320 CDI (V6 diesel). It is characterized by a high torque value that amounts to $630 \mathrm{~N} \cdot \mathrm{m}$ and nominal power of $210 \mathrm{~kW} \mathrm{[32].}$

\section{Sequential turbocharging}

Sequential turbocharging, widely applied in supercharged low speed marine engines $[3,17,18,19]$ received a great deal of attention as early as in the 1980s of the last century as a high potential method for the improvement of the properties of traction diesel engines, particularly heavy duty, high payload vehicles. In this period the application of this system was popular in gasoline passenger vehicles such as Audi, Fiat, Mercedes-Benz, Porsche [2, 19, 22, 29].

Sequential turbocharging consists in applying at least two turbochargers in a parallel configuration used proportionally to the power demand. The system of air flow control allows their gradual disconnection when the engine speed drops. As a result, a gradual decrease of the total area of the crosssection of the flow part of the turbines is used to increase the decompression level of the operating turbine and consequently to increase the compression rate of the turbine. Due to a proper selection of the turbocharger it can operate with higher efficiency. It leads to a significant improvement of the engine characteristics at low engine speeds. Smaller dimensions of a single turbocharger as opposed to a single stage turbochargers ensure a quick surge of the charging pressure as a response to the changes in the engine loads while the operation of the turbochargers in the parallel configuration limits the charging pressures in the area of nominal power. The advantage of sequential turbocharging is its low cost of modernization and the possibility of using serial production turbochargers. This allows the use of many combinations of turbochargers in order to provide the optimum enginecharger configuration. The system is characterized by highly adaptive qualities depending on the required engine power. This indicates a great potential for the reduction of fuel economy while the thermal and mechanical loads remain on an unchanged level. A disadvantage of sequential turbocharging is an abrupt pressure drop resulting from a stepwise actuation of the second compressor. The advantages of sequential turbocharging make this system recommendable for heavy duty, high payload vehicles, for which high torque at low speeds is desired. In the tests carried out by Volvo $[2,5,6]$ two turbochargers in two configurations were applied. The obrotowej powyżej 1800 1/min, w miarę otwierania zaworu włączającego turbinę w kanale obejściowym mniejszej turbiny, wielkość strumienia spalin przepływających bezpośrednio przez dużą turbosprężarkę rośnie, a przez małą maleje. W zakresie dużej prędkości obrotowej powyżej 3000 1/min na skutek wyrównania ciśnień roboczych obu sprężarek, otwiera się jednokierunkowy zawór zwrotny. Następuje również pełne otwarcie zaworu w kanale obejściowym mniejszej turbiny. W rezultacie tylko znikoma ilość czynnika przepływa przez małą turbinę i doładowanie realizowane jest przez większą turbosprężarkę. Układ ten zastosowano w silniku o ZS i wtrysku bezpośrednim typu common rail o objętości skokowej 1,9 $\mathrm{dm}^{3}$ oznaczonym jako Ecotec CDTI, znanym z samochodu Opel Vectra. Rozwija moc znamionową $156 \mathrm{~kW}$, o 50\% większą w stosunku do wersji podstawowej, przy spełnieniu surowych przepisów normy EURO 4, dotyczących zawartości substancji toksycznych w gazach wylotowych. Maksymalny moment obrotowy 400 $\mathrm{N} \cdot \mathrm{m}$ osiagany jest $\mathrm{w}$ zakresie $1400-3500$ 1/min [17]. Wartości średniego ciśnienia użytecznego 2,6 MPa oraz mocy jednostkowej $82 \mathrm{~kW} / \mathrm{dm}^{3}$ dla silników samochodowych tej klasy obecnie są uznawane za rekordowe.

Opracowano również rozwiązania tego systemu przeznaczone do silników widlastych, wykorzystujące dwie lub trzy turbosprężarki [28]. W pierwszym przypadku obie turbosprężarki mogą być umieszczone pomiędzy rzędami cylindrów, natomiast w drugim - mniejsze turbosprężarki stopnia wysokociśnieniowego mocowane są bezpośrednio do kolektorów wylotowych, a wspólna turbosprężarka stopnia niskociśnieniowego znajduje się pomiędzy rzędami cylindrów. Schemat takiego rozwiązania przedstawiono na rys. 6. Układ z trzema turbosprężarkami, określany jako Tri-turbo, znany jest z silnika o ZS V6 zastosowanego w 2005 r. w prototypie samochodu Mercedes-Benz SLK 320 CDI. Charakteryzuje się on dużą wartością maksymalnego momentu obrotowego, wynoszącą $630 \mathrm{~N} \cdot \mathrm{m}$ i mocą znamionową $210 \mathrm{~kW}$ [32].

\section{Doładowanie zakresowe (sekwencyjne)}

Doładowanie zakresowe znane i szeroko stosowane w wysoko doładowanych wolnoobrotowych silnikach okrętowych [3, 17, 18, 19] rozwijane było również w latach 80 . XX w. jako metoda o dużych potencjalnych możliwościach poprawy właściwości użytkowych trakcyjnych silników o ZS, w szczególności przeznaczonych do napędu samochodów ciężarowych dużej ładowności. Z tego okresu znane są przede wszystkim zastosowania tego systemu w silnikach samochodów osobowych z silnikami benzynowymi takich firm, jak np. Audi, Fiat, Mercedes-Benz, Porsche [2, 19, 22, 29].

Doładowanie zakresowe polega na zastosowaniu co najmniej dwóch turbosprężarek połączonych ze sobą równolegle, pracujących w zależności od zapotrzebowania na moc. Układ sterowania przepływem powietrza i spalin umożliwia ich stopniowe odłączanie przy spadku prędkości obrotowej silnika. Dzięki temu stopniowe zmniejszanie całkowitego pola powierzchni przekroju przepływowego turbin wykorzystywane jest do zwiększenia stopnia roz- 
first solution used turbochargers of the same size connected directly to the exhaust manifold (Fig. 7a). This allows a use of turbochargers with divided intakes of the turbine. The Turbines of this type adapted for pulse feed are fitted with separate intakes supplied with exhaust from selected group of cylinders. This leads to a better use of the kinetic energy of the exhaust gas. The second solution used turbochargers of different size of single intakes connected with the exhaust manifold of the engine through an impulse exchanger. Thanks to the application of the impulse exchanger splitting the stream of exhaust from the cylinders connected to separate exhaust ducts, the use of the kinetic energy of the exhaust in the turbochargers with undivided turbine intakes was possible (Fig. 7b).

The tests performed by Volvo on a six cylinder $12 \mathrm{dm}^{3}$ engine - TD121FD show that through the use of identical turbochargers (Fig. 8a) we can obtain a substantial increase in the torque value at low engine speeds. Yet, in order to avoid an excessive charging pressure the actuation of the other turbocharger is necessary already at the engine speed of $1100 \mathrm{1} / \mathrm{min}$. This example discloses a serious flaw of the system occurring while the turbochargers are being switched. When the second compressor is actuated, the compression rate drops below the compression rate for standard turbocharging. A considerable change in the charging pressure is accompanied by a sudden drop of the torque as the fuel dose has to be reduced due to excessive exhaust smokiness. Unitary fuel consumption increases as well. Figure $8 \mathrm{~b}$ shows the results of the tests on TD121FD fitted with a system using turbochargers of different size showing much better

a)

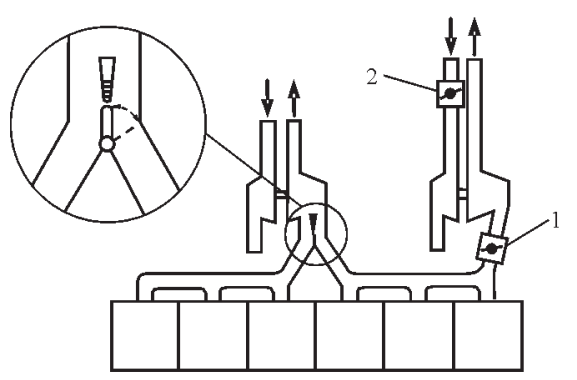

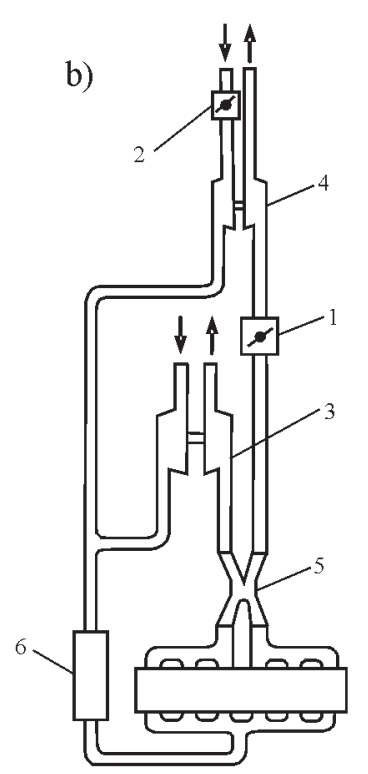

Fig. 7. Sequential turbocharging system: a - utilizing turbochargers of the same size, $b$ - utilizing turbochargers of different size and the impulse exchanger [2]: 1 - exhaust cutoff valve, 2 - air cutoff valve, 3 - larger turbocharger, 4 - smaller turbocharger, 5 - impulse exchanger, 6 - intercooler

Rys. 7. System doładowania sekwencyjnego: a - wykorzystujacy turbosprężarki jednakowej wielkości, b-wykorzystujacy turbosprężarki różnej wielkości oraz wymiennik impulsów [2]: 1 -zawór odcinajacy przepływ spalin, 2-zawór odcinajacy przeplyw powietrza, 3 - większa turbosprężarka, 4-mniejsza turbosprę-

żarka, 5-wymiennik impulsów, 6-chłodnica powietrza doładowanego prężania pracującej turbiny i w rezultacie do zwiększenia sprężu sprężarki. Dzięki odpowiedniemu dopasowaniu turbosprężarki może ona pracować z większą sprawnością. Prowadzi to do znaczącej poprawy charakterystyki silnika przy małej prędkości obrotowej. Mniejsze, w stosunku do doładowania jednostopniowego, wymiary pojedynczej turbosprężarki zapewniają szybki wzrost ciśnienia doładowania w odpowiedzi na zmiany obciążenia silnika, podczas gdy praca turbosprężarek w układzie równoległym ogranicza ciśnienia doładowania w obszarze mocy znamionowej. Zaletą doładowania zakresowego jest mały koszt modernizacji oraz możliwość wykorzystania seryjnie produkowanych turbosprężarek. Pozwala to na stosowanie wielu kombinacji turbin i sprężarek, w celu zapewnienia optymalnego dostosowania turbosprężarek do silnika. Dzięki temu system ten cechuje się bardzo dobrymi możliwościami adaptacji w zależności od wymaganej mocy silnika. Wskazuje to na jego znaczny potencjał w zmniejszeniu zużycia paliwa przy utrzymaniu obciążeń mechanicznych i cieplnych o zbliżonej wartości do silnika standardowego. Niedogodnością doładowania zakresowego jest gwałtowny spadek ciśnienia doładowania wynikający ze skokowego włączania drugiej turbosprężarki. Zalety doładowania zakresowego czynią ten system bardzo odpowiedni dla silników samochodów ciężarowych dużej ładowności, w których pożądane jest uzyskiwanie dużych wartości momentu obrotowego przy małej prędkości obrotowej. W badaniach prowadzonych przez Volvo $[2,5,6]$ zastosowano po dwie turbosprężarki w dwóch konfiguracjach. Pierwsze rozwiązanie wykorzystywało turbosprężarki jednakowej wielkości podłączone bezpośrednio do układu wylotowego (rys. 7a). Umożliwiało to zastosowanie turbosprężarek z dzieloną skrzynią wlotową turbiny. Turbiny tego typu przystosowane do pulsacyjnego zasilania wyposażone są w oddzielne kanały wlotowe zasilane spalinami z kilku zgrupowanych cylindrów silnika. Prowadzi to do lepszego wykorzystania energii kinetycznej spalin zasilających turbiny. Drugie rozwiązanie wykorzystywało turbosprężarki różnej wielkości o niedzielonych skrzyniach wlotowych, połączonych z układem wylotowym silnika za pośrednictwem wymiennika impulsów. Dzięki zastosowaniu wymiennika impulsów rozdzielającego strumień spalin z cylindrów połączonych do oddzielnych przewodów wylotowych możliwe było wykorzystanie energii kinetycznej spalin w turbosprężarkach z pojedynczymi kanałami wlotowymi turbin (rys. 7b).

Z badań przeprowadzonych przez Volvo na sześciocylindrowym silniku TD121FD o objętości skokowej $12 \mathrm{dm}^{3}$ wynika, że przy zastosowaniu jednakowych turbosprężarek (rys. 8a) można uzyskać znaczny wzrost momentu obrotowego przy małej prędkości obrotowej. Aby jednak uniknąć nadmiernego wzrostu ciśnienia doładowania, konieczne jest włączenie drugiej turbosprężarki już przy prędkości obrotowej 1100 1/min. Uwidacznia się tutaj w sposób szczególny istotna niedogodność tego systemu występująca podczas przełączania turbosprężarek. Kiedy włączana jest druga 
performance properties for both external characteristics and part loads. As opposed to a conventionally turbocharged engine, the charging pressure is higher with the range of operation of one turbocharger. This also contributed to the increase in the engine torque. On actuating of the second turbocharger at $1650 \mathrm{1} / \mathrm{min}$ the torque is reduced as well but this drop is relatively small. It is a result of a better matching of the turbocharger and engine characteristics, the smaller turbocharger in particular.

a)

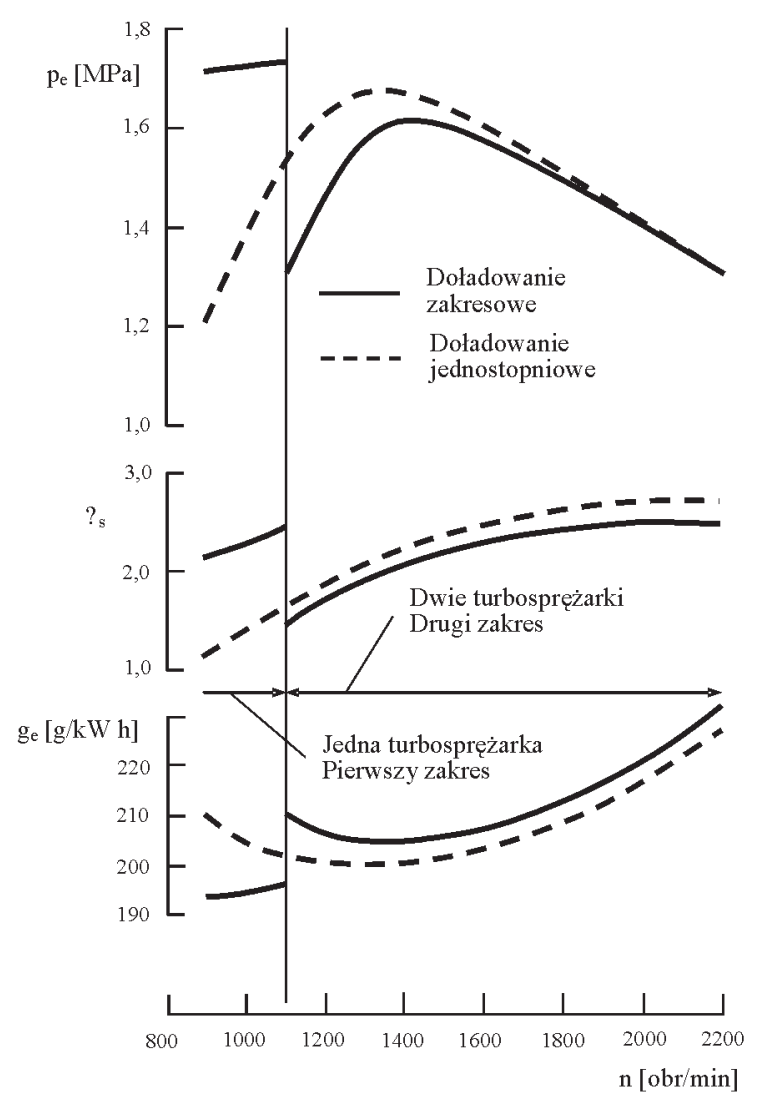

turbosprężarka, spręż spada poniżej wartości sprężu przy doładowaniu konwencjonalnym. Dużej chwilowej zmianie ciśnienia doładowania towarzyszy gwałtowny spadek momentu obrotowego, gdyż dawka paliwa musi być ograniczona ze względu na nadmierny wzrost zadymienia spalin. Wzrasta również jednostkowe zużycie paliwa. Na rysunku $8 b$ przedstawiono wyniki badań silnika TD121FD z systemem wykorzystującym turbosprężarki różnej wielkości, który wykazuje znacznie lepsze właściwości użytkowe, zarówno

b)

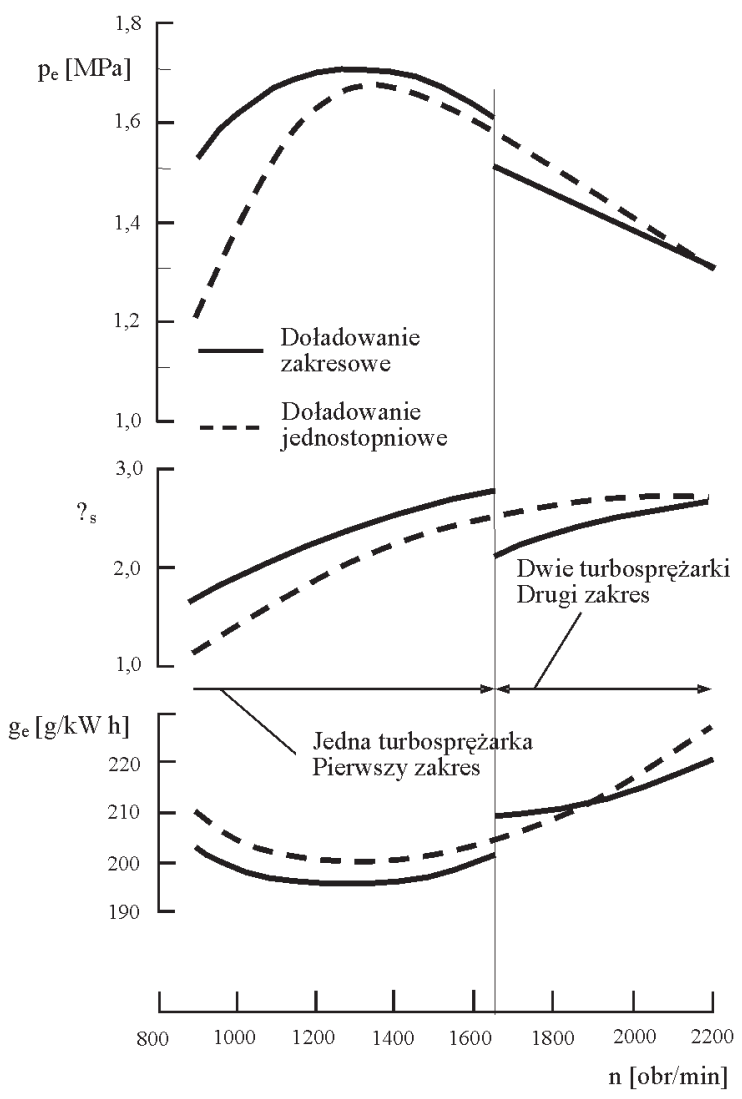

Fig. 8. External characteristics of a TD121FD engine at the same nominal power of a conventionally turbocharged and sequentially turbocharged ver-

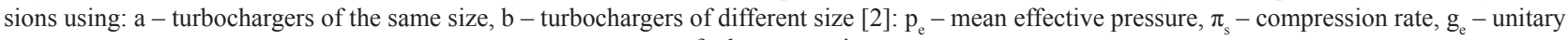
fuel consumption

Rys. 8. Charakterystyka zewnętrzna silnika TD121FD przy tej samej mocy znamionowej doładowanego konwencjonalnie oraz z doładowaniem sekwencyjnym wykorzystujacym turbosprężarki: a-jednakowej wielkości, b-różnej wielkości [2]: $p_{e}$ - średnie ciśnienie użyteczne, $\pi_{s}$ - spręż, $g_{e}$-jednostkowe zużycie paliwa

The lack of continuity of engine characteristics, typical of sequential turbocharging, indicates the necessity to seek solutions improving the cooperation of the engine with the charging system, particularly while the turbochargers are being switched. The problem solving concept by Audi [2] consisted in the application of an additional bleed valve in the system controlling the exhaust flow through the turbochargers (Fig. 9a), which would open as the pressure generated by the first turbocharger reached the required value. Thanks to the exhaust flowing towards the second turbocharger in the initial phase of its opening it was possible to avoid the exhaust pressure drop. In the intake manifold (Fig. 9b) apart na charakterystyce zewnętrznej, jak i przy obciążeniach częściowych. W stosunku do silnika doładowanego konwencjonalnie, ciśnienie doładowania jest większe w zakresie pracy jednej turbosprężarki. Przyczyniło się to również do zwiększenia momentu obrotowego. Po włączeniu drugiej turbosprężarki przy 1650 1/min moment obrotowy również ulega zmniejszeniu, lecz jest to spadek stosunkowo niewielki. Jest to wynikiem lepszego dopasowania charakterystyk silnika oraz turbosprężarek, w szczególności mniejszej turbosprężarki drugiego zakresu.

Typowa dla doładowania sekwencyjnego nieciągłość charakterystyk silnika wskazuje na celowość poszukiwania 
from the cutoff valve of the second compressor, an air bleed valve was fitted. While the cutoff valve was closed the air, partially compressed by the actuated compressor, was directed through the bleed valve to its intake. Due to a reduction of the compression work it was possible to obtain higher accelerations of the turbo-rotor, which enabled to shorten the switching time of the turbochargers. When the pressure in the two turbochargers equalized, the opening of the cutoff valve caused the air flow to the engine from the second compressor. The characteristics of the $2.2 \mathrm{dm}^{3}$ Audi engine obtained during the tests indicate a much more advantageous course of torque (comparable to an unsupercharged engine of the same nominal power) as opposed to conventional turbocharging and the system of two compressors connected in a rozwiązań usprawniających współpracę silnika i zespołu doładowującego, szczególnie w okresie przełączania turbosprężarek. Koncepcja rozwiązania tego problemu zaprezentowana przez Audi [2] polegała na zastosowaniu dodatkowego zaworu upustowego spalin w układzie sterującym przepływem spalin przez turbosprężarki (rys. 9a), który otwierał się, gdy ciśnienie doładowania wytwarzane przez pierwszą turbosprężarką osiagnęło wymaganą wartość. Dzięki skierowaniu upuszczanych spalin na wlot do drugiej turbiny w początkowej fazie jej włączania możliwe było uniknięcie spadku ciśnienia spalin. W układzie dolotowym (rys. 9b) oprócz zaworu odcinającego drugiej sprężarki zastosowano zawór upustowy powietrza. Przy zamkniętym zaworze odcinającym, częściowo sprężone powietrze przez a)

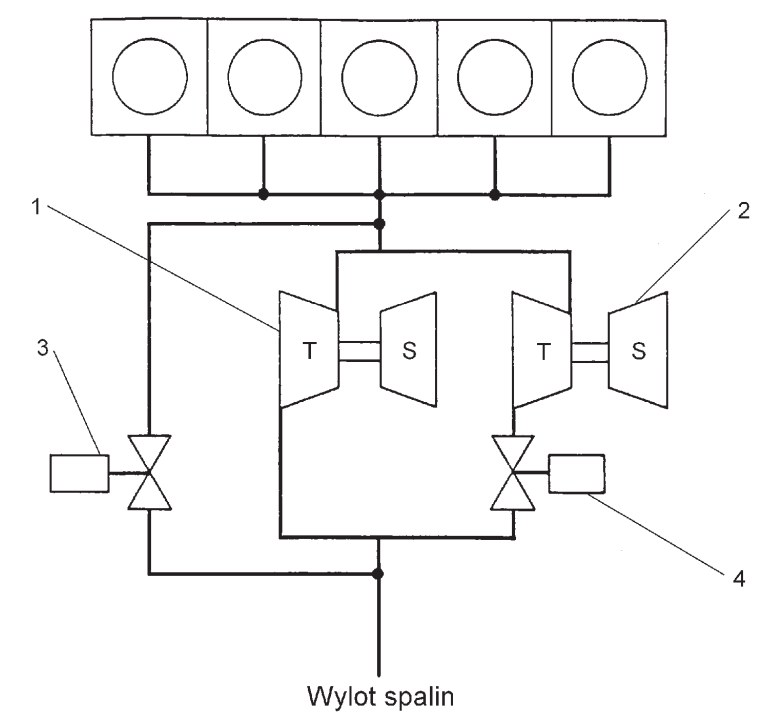

b)

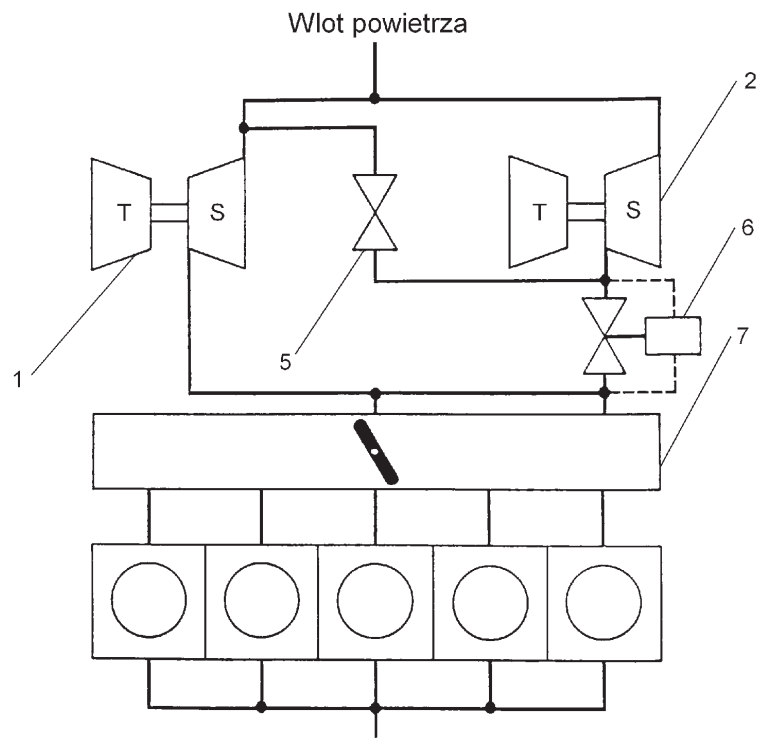

Fig. 9. Schematics of the sequential turbocharging by Audi [2]: a - exhaust flow control system, b - air flow control system, 1 - first stage turbocharger, 2 - second stage turbocharger, 3 - wastegate, 4 - valve actuating the turbine, 5 - air bleed valve, 6 - valve actuating the compressor, 7 - intake manifold

Rys. 9. Schemat doładowania sekwencyjnego silnika Audi [2]: a-układ sterowania przepływem spalin, b-uktad sterowania przepływem powietrza, 1 - turbosprężarka pierwszego zakresu, 2 - turbosprężarka drugiego zakresu, 3 -zawór upustowy spalin, 4-zawór włqczajacy turbinę, 5 - zawór upustowy powietrza, 6-zawór właczajacy sprężarke, 7 - kolektor dolotowy

parallel configuration, particularly at low engine speeds. The application of electronic control enabled the optimization of the switching process. The obtained results show a merely $7 \%$ extension of the vehicle acceleration time, which can be compared to the application of automatic transmission.

Development works have also been undertaken by the PSA Group collaborating with Ford Motor Company. This resulted in a new $2.2 \mathrm{dm}^{3} \mathrm{HDI}$ diesel engine as the first four cylinder engine using this technology. The engine utilizes two identical constant geometry turbochargers [31]. This system is similar to that of Volvo in its diesel engines for high payload heavy duty vehicles. At lower engine speed only one turbocharger operates. The actuation of the second turbocharger comes with the engine speed of 2600 to 3200 włączaną sprężarkę kierowane było przez zawór upustowy na jej wlot. Dzięki zmniejszeniu pracy sprężania możliwe było uzyskanie większych przyspieszeń wirnika, co pozwoliło skrócić okres przełączania turbosprężarek. Gdy ciśnienia na wylocie z obu sprężarek uległy wyrównaniu, otwarcie zaworu odcinającego powodowało przepływ powietrza do silnika z drugiej sprężarki. Uzyskane podczas badań charakterystyki silnika Audi o objętości skokowej 2,2 $\mathrm{dm}^{3}$ wskazują na znacznie korzystniejszy, szczególnie w zakresie niskich prędkości obrotowych, przebieg momentu obrotowego w stosunku do doładowania konwencjonalnego oraz układu z dwoma turbosprężarkami połączonymi równolegle, porównywalny z silnikiem niedoładowanym o tej samej mocy znamionowej. Zastosowanie elektronicznego sterowania 
$1 /$ min, depending on the load and atmospheric conditions, which allows a necessary air flow in the whole range of high engine speeds. Similarly to the Porsche solution [19] the transient phase enables the running up of the compressor being actuated. This makes the mode shift much smoother. This engine, known from Peugeot 407, 607 and 807 as well as Citroen C5 and C6 has the power of $125 \mathrm{~kW}$ at 4000 $1 / \mathrm{min}$. The maximum torque is reached at $15001 / \mathrm{min}$ and amounts to $370 \mathrm{~N} \cdot \mathrm{m}$, i.e. approximately $30 \%$ more than in the base engine, still complying with the Euro 4 emission standard.

\section{Results of own tests on the engine with sequen- tial turbocharging}

The tests related to the improvement of the operation of turbocharged diesel engines are also carried out at the Chair of Automotive Vehicles Operation of Szczecin Univeristy of Technology. It is the only scientific center in Poland where for many years tests have been carried out on the sequential turbocharging application in automotive engines. The object of the tests was a direct injection engine by PZL-Mielec

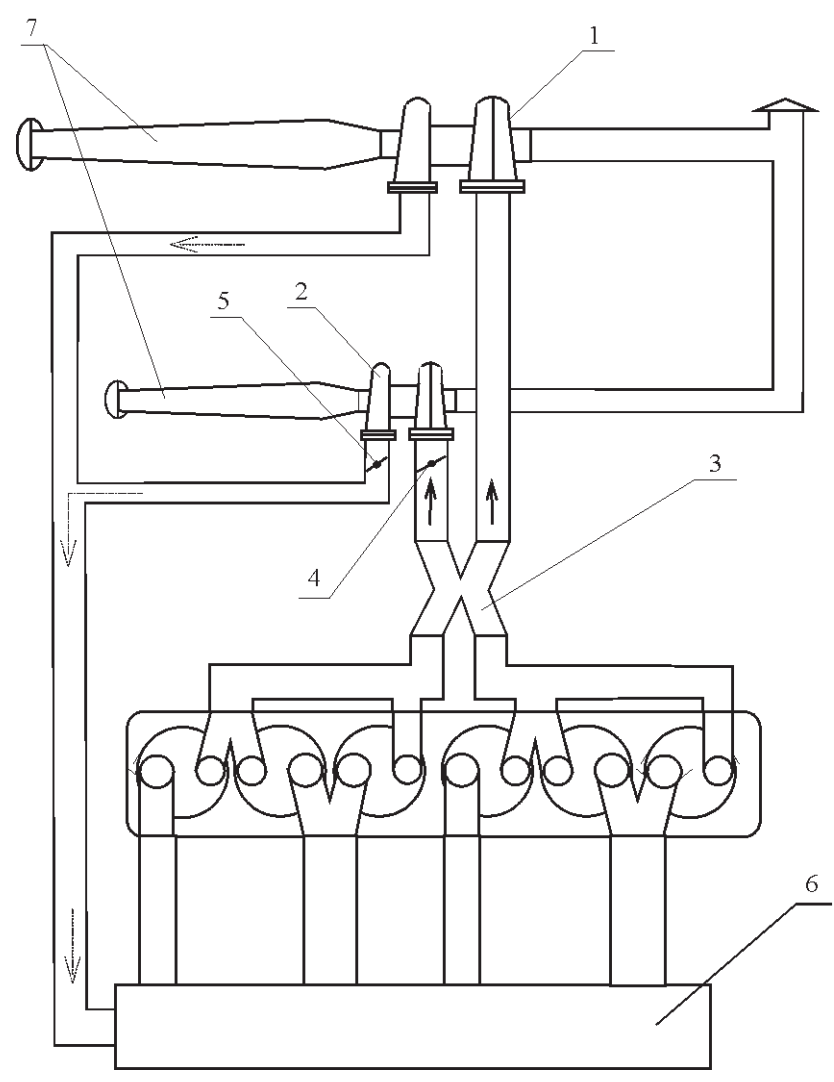

Fig. 10. Schematics of the sequential turbocharging system developed at Chair of Automotive Vehicles Operation: 1 - larger turbocharger,

2 - smaller turbocharger, 3 - junction, 4 - throttle between the turbine and the engine, 5 - throttle between the compressor and the engine, 6 - intake manifold, 7 - air intake adapted to the measurement of the gas delivery rate

Rys. 10. Schemat układu doładowania sekwencyjnego zbudowany w KEPS: 1 - większa turbosprężarka, 2 - mniejsza turbosprężarka, 3 -rozgałęzienie, 4-przepustnica między turbinq a silnikiem, 5-przepustnica między sprężarkq a silnikiem, 6-kolektor dolotowy, 7-wlot powietrza przystosowany do pomiaru wydatku pozwoliło optymalizować proces przełączania. Uzyskane wyniki wskazują na zaledwie 7-procentowe zwiększenie czasu przyspieszania pojazdu, co jest porównywalne z zastosowaniem automatycznej skrzyni biegów.

Prace rozwojowe nad systemem doładowania zakresowego podjęła również grupa PSA przy współpracy z Ford Motor Company. Zaowocowały one wprowadzeniem do produkcji silnika o objętości skokowej 2,2 $\mathrm{dm}^{3}$ typu HDI jako pierwszego na świecie czterocylindrowego silnika ZS wyposażonego w tę technologię. Wykorzystuje on dwie turbosprężarki jednakowej wielkości o stałej geometrii przepływu spalin [31]. Jest to układ podobny do stosowanego przez Volvo w silnikach o ZS przeznaczonych do napędu samochodu ciężarowego o dużej ładowności. Przy niższej prędkości obrotowej działa tylko jedna turbosprężarka. Włączenie drugiej turbosprężarki następuje między 2600 a 3200 1/min, w zależności od obciążenia i warunków atmosferycznych, co pozwala zapewnić niezbędny przepływ powietrza w całym zakresie wysokich prędkości obrotowych. Podobnie jak w rozwiązaniu Porsche [19] faza przejściowa umożliwia rozpędzenie wirnika włączanej turbosprężarki. Pozwala to na łagodniejsze przejście do drugiego trybu pracy. Silnik ten znany z samochodów Peugeot 407, 607 i 807 oraz Citroën C5 i C6 rozwija moc znamionowa $125 \mathrm{~kW}$ przy 4000 1/min. Maksymalny moment obrotowy osiagany przy 1500 1/min wynosi $370 \mathrm{~N} \cdot \mathrm{m}$, o ok. 30\% więcej niż w silniku bazowym, spełniając wymagania normy Euro 4.

\section{Wyniki badań własnych silnika samochodowego z doladowaniem sekwencyjnym}

Badania nad możliwością poprawy parametrów pracy turbodoładowanych silników o ZS prowadzone są również w laboratoriach Katedry Eksploatacji Pojazdów Samochodowych Politechniki Szczecińskiej. Jest to jedyny ośrodek w Polsce, w którym od wielu lat prowadzone są prace nad zastosowaniem doładowania zakresowego w silnikach samochodowych. Jako obiekt badań wykorzystany został silnik produkcji PZL-Mielec SW-680 o wtrysku bezpośrednim. Silnik ten należy do grupy klasycznych silników o ZS stosowanych m.in. w starszych wersjach samochodów ciężarowych dużej ładowności. W konstrukcji badanego silnika wprowadzono wiele zmian, które polegały w głównej mierze na modyfikacji układu dolotowego i wydechowego oraz na wykonaniu dodatkowych elementów sterujących przepływem powietrza i spalin. Schemat systemu doładowania sekwencyjnego silnika SW-680 przedstawiono na rys. 10. Podstawowe dane techniczne silnika SW-680 oraz dokładny opis działania układu zawarty jest m.in. w pracach $[9,10]$.

$\mathrm{W}$ badaniach wykorzystano dostępne na rynku turbosprężarki produkcji WSK Rzeszów typoszeregu B3A, B3C oraz B65. Użyto sprężarki o numerach katalogowych wirników: 259K, 279K, 309K dla sprężarek pierwszego zakresu oraz sprężarki typoszeregu B65 o numerach katalogowych wirników 50, 60 dla drugiego zakresu. Dla wszystkich sprężarek zastosowano różne konfiguracje wielkości turbin. Wyniki badań wstępnych silnika SW-680 z doładowaniem sekwencyjnym, prezentowane m.in. w pracach autora [11, 
SW-680. This engine falls into the category of classic diesel engines fitted in older high payload heavy duty vehicles. Several modifications were introduced to the design of this engine such as in particular the intake and exhaust manifold modifications as well as the addition of air and exhaust flow controlling elements. The schematics of the sequential turbocharging system of SW-680 has been presented in Fig. 10. The basic technical specifications of this engine as well as a detailed description of the system operation is more extensively discussed in such works as $[9,10]$.

During the tests, WSK Rzeszów, type B3A, B3C and B65 - serially manufactured turbochargers were used. The turbochargers type: $259 \mathrm{~K}, 279 \mathrm{~K}, 309 \mathrm{~K}$ for first stage and B65 for the second stage and the rotors of catalogue numbers 50 and 60 for the second stage were used. For all the turbochargers different configurations of turbine size were applied. The initial tests results of the sequentially turbocharged SW-680 engine, presented, among others, in the author's works [11, $12,23,24]$, made it possible to evaluate the applicability of each of the turbochargers, out of which the turbochargers: B3C-309K with the intake AT $=17 \mathrm{~cm}^{2}$ and $65-60$ with the intake $\mathrm{AT}=5.65 \mathrm{~cm}^{2}$ were used for further research.

In order to fully use the potential for the improvement of the engine characteristics related to the application of smaller turbochargers, as opposed to single stage turbocharging, a modification of the fuel dosage was instituted. The evaluation took into account the assumed limitation resulting

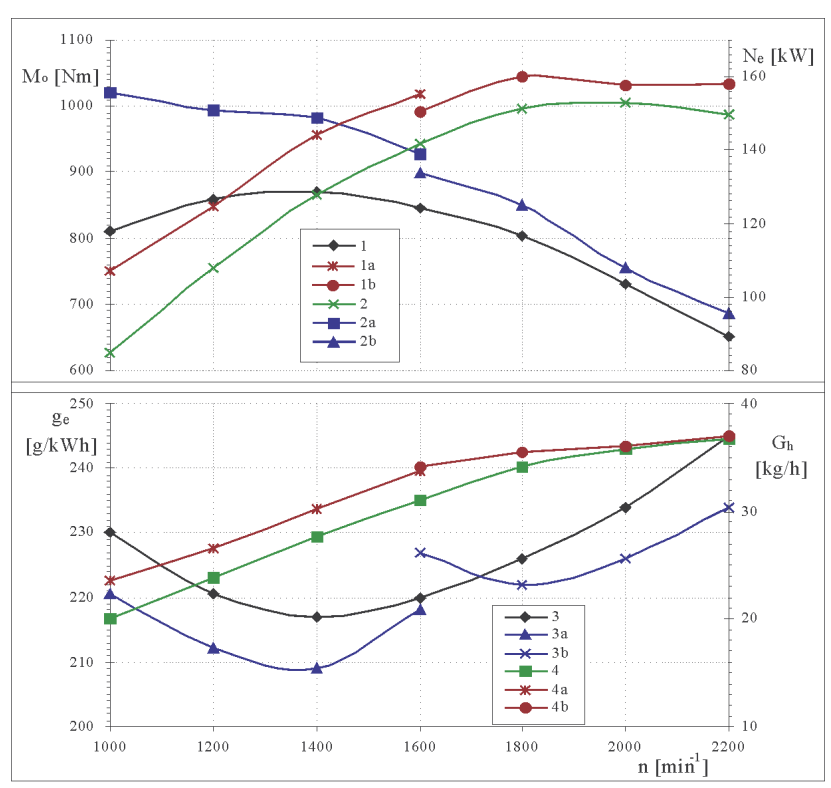

Fig. 11. External engine characteristics - SW-680 sequentially turbocharged and conventionally turbocharged [9]; 1 - torque, 2 - power,

3 - unitary fuel consumption, 4 - hourly fuel consumption (original turbocharger marked B4A) 1a, 1b - torque; 2a, 2b-power;

$3 \mathrm{a}, 3 \mathrm{~b}$ - unitary fuel consumption; $4 \mathrm{a}, 4 \mathrm{~b}$ - hourly fuel consumption (sequential turbocharging)

Rys. 11. Charakterystyka zewnętrzna silnika $S W-680$ z doładowaniem sekwencyjnym oraz doładowanego konwencjonalnie [9]; 1 - moment obrotowy, 2-moc, 3 -jednostkowe zużycie paliwa, 4-godzinowe zużycie paliwa silnika z turbosprężarkq oryginalnq

o oznaczeniu B4A. 1a, 1b-moment obrotowy; $2 a, 2 b-$ moc; $3 a, 3 b-$

jednostkowe zużycie paliwa; $4 a, 4 b$ - godzinowe zużycie paliwa silnika $z$ doładowaniem zakresowym
12, 23, 24], umożliwiły ocenę przydatności każdej z użytych turbosprężarek, z których w dalszych próbach wykorzystano turbosprężarki: B3C-309K ze skrzynią wlotową $\mathrm{A}_{\mathrm{T}}=17 \mathrm{~cm}^{2}$ oraz B65-60 ze skrzynią wlotową $A_{T}=5,65 \mathrm{~cm}^{2}$.

W celu pełnego wykorzystania potencjalnych możliwości poprawy charakterystyk silnika związanych z zastosowaniem mniejszych, w porównaniu do doładowania jednostopniowego, turbosprężarek dokonano odpowiedniej korekcji dawkowania paliwa. W ocenie uwzględniono przyjęte ograniczenie wynikające z dopuszczalnych obciążeń mechanicznych, cieplnych oraz zadymienia spalin, które nie mogły odbiegać od wartości dla silnika seryjnego doładowanego konwencjonalnie. Wyniki tych badań w porównaniu do silnika seryjnego doładowanego turbosprężarką B4A ilustruje rys. 11. W wyniku tych działań uzyskano znaczny wzrost momentu obrotowego w całym zakresie użytecznych prędkości obrotowych. Przy tym maksymalny moment obrotowy, który o ponad 20\% przewyższa jego wartość w silniku seryjnym, osiagany jest przy najmniejszej prędkości obrotowej. Odpowiada to zwiększeniu współczynnika elastyczności silnika do wartości 3,30 przy współczynniku 1,88 dla silnika doładowanego konwencjonalnie. Biorąc pod uwagę, że silnik ten stosowany był w starszych wersjach samochodów ciężarowych jest to wynik bardzo dobry, porównywalny z nowoczesnymi silnikami turbodoładowanymi z chłodzeniem powietrza oraz pompowtryskiwaczami czy układami typu common rail [25]. Mniejsze jest również jednostkowe zużycie paliwa. Jednak i w tym przypadku ujawniła się niedogodność doładowania sekwencyjnego, która prowadzi do nieciągłości charakterystyki silnika. Wynika to ze skokowego włączania do pracy turbosprężarki drugiego zakresu, co następuje przy prędkości obrotowej $16001 /$ min. Prowadzi to do pogorszenia parametrów pracy silnika w tym obszarze charakterystyki. Jest to jednak zjawisko typowe dla doładowania sekwencyjnego i znalazło odbicie w prezentowanych wcześniej rozwiązaniach tego typu.

Po włączeniu drugiej turbosprężarki, gdy ciśnienie doładowania spada poniżej wartości silnika seryjnego, jednostkowe zużycie paliwa początkowo rośnie, jednak przy wzroście prędkości obrotowej osiaga wartości niższe o ok. $5 \%$. Natomiast zadymienie spalin w znacznym obszarze drugiego zakresu jest wyższe niż w silniku seryjnym. Wzrost zadymienia spalin zaobserwowano również przy niewielkich obciążeniach silnika podczas pracy silnika z dużym nadmiarem powietrza. Wskazuje to na konieczność zmian regulacji układu wtryskowego. Poprawa ekonomiczności w całym zakresie użytecznych prędkości obrotowych wynika z właściwego dopasowania turbosprężarek. Prowadzi to do zmniejszenia pracy sprężania, znacznie poprawia warunki wymiany ładunku i w dużym stopniu kompensuje spadek sprawności cieplnej silnika w zakresie pracy dwóch turbosprężarek. Na rysunku 12 przedstawiono charakterystyki przepływowe sprężarek pierwszego oraz drugiego zakresu z naniesionymi liniami współpracy z silnikiem SW-680. Z położenia linii współpracy z silnikiem wynika, że na charakterystyce większej sprężarki B3C zarówno w pierwszym, jak i drugim zakresie prędkości obrotowych, przebiegają one przez obszary o dużej sprawności i w znacznej odległości 
from the maximum mechanical and thermal loads as well as the smokiness, which had to stay within the values of a conventionally turbocharged engine. The results of these tests, against a serially manufactured engine turbocharged with a B4A have been presented in Fig. 11. As a result of the modifications, a significant growth in the torque value was obtained in the whole range of usable engine speeds and the value of the maximum torque itself higher by more than $20 \%$ was reached at the lowest engine speed. The coefficient of dynamics rises to 3.30 while the same coefficient for a conventionally turbocharged engine amounts to 1.88 . Taking into account that this engine was fitted in older versions of the heavy duty vehicles it is a very good result - a result comparable with modern turbocharged intercooled pumpnozzle or common rail engines [25]. The unitary fuel consumption was also lower. However, even in this case, a flaw of the sequential turbocharging was disclosed, leading to a lack of continuity of the engine characteristics. It results from the stepwise actuation of the second stage turbocharger, which occurs at the engine speed of $1600 \mathrm{1} / \mathrm{min}$. It leads to a deterioration of the engine operating parameters in this area of characteristics. It is a typical phenomenon for sequential turbocharging and is known from previous solutions of this type.

After the second turbocharger is actuated, when the charging pressure drops below the value of a serially manufactured engine, the unitary fuel consumption initially increases but, as the engine speed grows, the values drop by approximately $5 \%$. Yet, the smokiness in most of the area of the second stage is higher than in a serially manufactured engine. An increase in smokiness has also been observed at small loads and high air excess coefficient. This indicates a necessity to adjust the injection system. The improvement of the fuel economy in the whole range of usable engine speeds is a result of an appropriate matching of the turbochargers. This leads to a reduction of the compression work, improves the conditions of charge exchange and, to a large extent, compensates the drop of the engine thermal efficiency in the work range of two turbochargers. Figure 12 presents the flow characteristics of first and second stage turbochargers with visible lines of cooperation with the SW-680 engine. The location of these lines indicates that on the characteristics of the larger turbocharger B3C in both the first and the second range of engine speeds the lines go through the areas of high efficiency and are far from the pumping limit. The cooperation of the engine with the smaller turbocharger B65-60 in the second range of engine speeds is flawless as well. This confirms the proper matching of the turbochargers and the engine.

The presented results of the test bed investigations indicate that the application of sequential turbocharging allows a significant improvement of the effective engine indexes in the external characteristics. It is particularly noticeable at low engine speeds and is a result of a significant growth of the od granicy pompowania. Współpraca z silnikiem mniejszej sprężarki B65-60 w drugim zakresie prędkości obrotowych również nie budzi zastrzeżeń. Świadczy to o prawidłowości doboru turbosprężarek do silnika.

Zaprezentowane wyniki badań hamownianych wskazuja, że zastosowanie doładowania sekwencyjnego pozwala na znaczną poprawę efektywnych wskaźników pracy silnika w warunkach charakterystyki zewnętrznej. Jest to szczególnie widoczne w zakresie niskich prędkości obrotowych i jest wynikiem znacznego wzrostu ciśnienia doładowania. Jednak w przypadku silnika trakcyjnego należy brać pod uwage rzeczywisty rozkład obciążeń występujący w typowych warunkach eksploatacji pojazdu. Zaobserwowano m.in.,

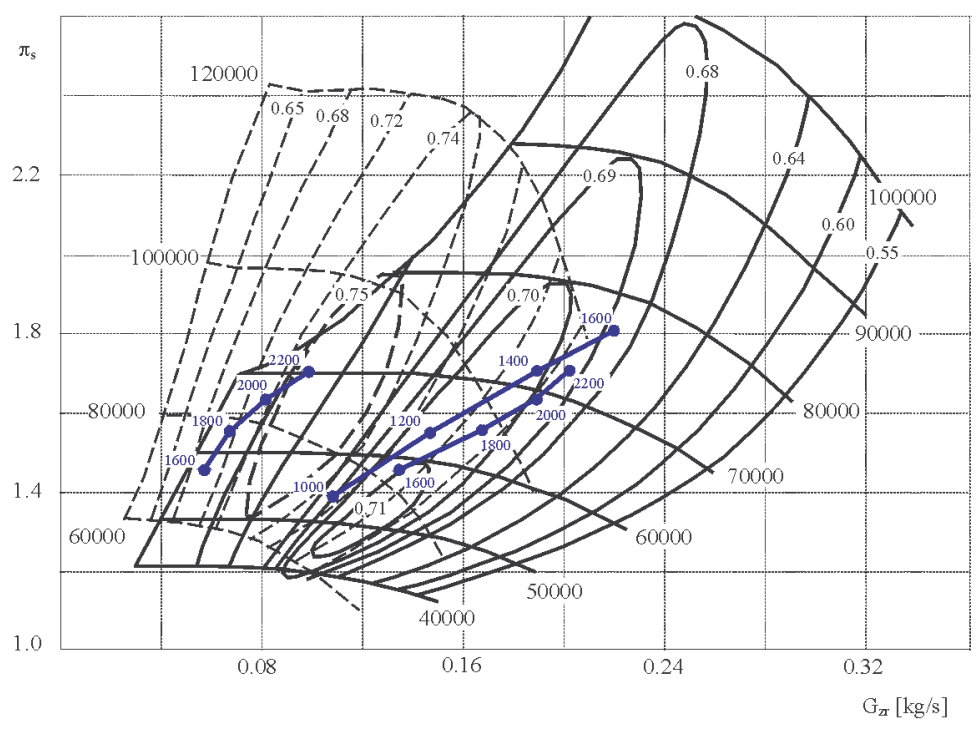

Fig. 12. Flow characteristics of turbochargers: first stage B3C second stage B65 with intake $\mathrm{AT}=5.65 \mathrm{~cm}^{2}$ in a sequential turbocharging configuration with visible lines of cooperation with the SW-680 engine

Rys. 12. Charakterystyki przeplywowe sprężarek: pierwszego zakresu B3C oraz drugiego zakresu $B 65$ ze skrzynia wlotowa turbiny $A_{T}=5,65 \mathrm{~cm}^{2} w$ uktadzie doładowania sekwencyjnego z naniesionymi liniami wspótpracy z silnikiem $\mathrm{SW}-680$ że pomimo wyższych ciśnień doładowania, ekonomiczność pracy w zakresie niskich i średnich obciążeń silnika uległa pogorszeniu. Skłoniło to do oceny pracy układu przy obciążeniach częściowych silnika. Na podstawie przeprowadzonych badań symulacyjnych z wykorzystaniem numerycznego modelu silnika i turbosprężarkowego zespołu doładowującego oraz badań weryfikacyjnych na hamowni silnikowej określono obszary pracy silnika $\mathrm{z}$ jedną oraz z dwoma turbosprężarkami. Położenie obszarów określono w oparciu o kryterium uzyskania najwyższej ekonomiczności pracy silnika ocenianej na podstawie charakterystyk obciążeniowych jednostkowego zużycia paliwa silnika pracującego $\mathrm{z}$ jedną oraz z dwoma turbosprężarkami. Charakterystyki obciążeniowe jednostkowego zużycia paliwa posłużyły do sporządzenia charakterystyki uniwersalnej (rys. 13), na którą naniesiono linię graniczną określającą charakterystyczne obszary pracy silnika. Poniżej linii znajduje się obszar pracy silnika z dwoma turbosprężarkami, zaś powyżej linii - z jedną turbosprężarką. 
charging pressure. Yet, in the case of a traction engine, we have to consider the actual distribution of loads occurring under typical vehicle operating conditions. It has been observed that despite higher charging pressures the operating economy at low and medium engine loads deteriorated. This pushed the authors to evaluate the engine operation under part loads. Based on the simulation research with the use of a numerical engine model and the turbocharging system as well as the validation tests on a test bed, areas of engine work have been determined with one and two turbochargers. The location of these areas has been determined based on the highest engine economy criterion evaluated through the characteristics of unitary fuel consumption at different loads for the engine operating with one and two turbochargers. The characteristics of unitary fuel consumption at different loads were used to create a general characteristics (Fig. 13), on which a boundary line was drawn that determined the characteristic areas of engine operation. Below the line there is the area of engine operation with two turbochargers, and above - one turbocharger. The course of the boundary line allowed determining the required functional properties of the turbocharging system, the switching system and the air and exhaust flow control elements. This constituted the basis for the development of models and algorithms for the electronic turbocharger control system. The engine speed and load were assumed as the controlling quantities, which were determined based on the charging pressure. The course of the boundary of engine economy was described through the control algorithm in the form of a multinomial. This allowed the calculation of the pressure depending on the engine speed at which the switching of the turbochargers occurred. The tests performed with the electronic control system helped verify the model calculations and the proposed design and setting solutions as well as determine the trends for further research aiming at the improvement of the operating properties of sequentially turbocharged engines. A detailed description of the control algorithm and the tests results of the engine with the said control system have been presented in works $[9,13,15]$.

\section{Conclusions}

The above presented efforts by international automotive concerns indicate that despite a high level miniaturization and technological advancement of VTG turbochargers the industry is still seeking ways to improve the operation of the engine-turbocharger pair. In sequential turbocharging and its varieties, thanks to little inertia of the used turbochargers and the application of electronic control, it is possible for the engine to accelerate on a level comparable to unsupercharged gasoline engines. The application of the smaller turbocharger used in the range of low engine speeds and loads is of particular importance compared to a single stage turbocharging. Thanks to this solution an appropriate engine reaction time for the changing of the operating conditions is ensured even at a low mass and energy of the exhaust flowing through the turbine. This solution also provides a more advantageous course of the torque in the whole range of engine speeds. At the same time a better adaptation of the compressor to mo-

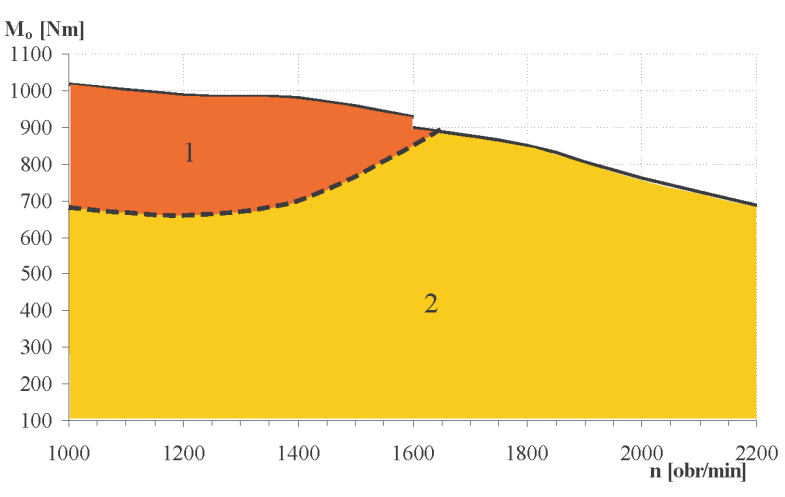

Fig. 13. Universal characteristics of the engine $-\mathrm{SW}-680$ sequentially turbocharged with indicated areas of engine work: 1 - with one turbocharger, 2 - with two turbochargers

Rys. 13. Charakterystyka uniwersalna silnika $S W-680$ z doładowanie sekwencyjnym, z zaznaczonymi obszarami pracy silnika: 1 - z jedna turbosprężarka, $2-z$ dwoma turbosprężarkami

Wyznaczony przebieg linii granicznej pozwolił na określenie wymaganych właściwości funkcjonalnych zespołu doładowującego, układu przełączającego oraz elementów sterujących przepływem powietrza i spalin. Stanowiło to podstawę do opracowania modeli oraz algorytmów dla elektronicznego systemu sterowania pracą turbosprężarek. Jako wielkości sterujące przyjęto prędkość obrotową oraz obciążenie silnika, które określano na podstawie ciśnienia doładowania. Przebieg granicy ekonomiczności opisano w algorytmie sterowania w postaci wielomianu. Pozwalało to na obliczenie ciśnienia w zależności od prędkości obrotowej, przy którym następowało przełączenie turbosprężarek. Przeprowadzone próby z elektronicznym systemem sterowania umożliwily weryfikację obliczeń modelowych oraz proponowanych rozwiązań konstrukcyjnych i regulacyjnych oraz pozwoliły wyznaczyć kierunki dalszych badań mających na celu poprawę właściwości użytkowych silnika z systemem doładowania sekwencyjnego. Szczegółowy opis algorytmu sterowania oraz wyniki badań silnika $\mathrm{z}$ opracowanym systemem sterowania przedstawiony został w pracach $[9,13,15]$.

\section{Podsumowanie}

Przedstawione wyżej działania realizowane przez koncerny motoryzacyjne wskazują, iż pomimo osiagnięcia wysokiego stopnia miniaturyzacji oraz technologicznego rozwoju turbosprężarek typu VTG, trwają dalsze poszukiwania metod usprawnienia współpracy zespołu silnik-turbosprężarka. W doładowaniu zakresowym oraz jego odmianach dzięki małej bezwładności wykorzystywanych turbosprężarek oraz zastosowaniu elektronicznego sterowania możliwe jest uzyskiwanie zdolności silnika do przyspieszania, porównywalnej z niedoładowanymi silnikami o ZI. Szczególne znaczenie ma zastosowanie mniejszej, w porównaniu do doładowania jednostopniowego, turbosprężarki wykorzystywanej w zakresie niskich prędkości obrotowych oraz obciążeń silnika. Dzięki temu zapewniona jest odpowiednia szybkość reakcji silnika na zmiany warunków pracy silnika, nawet przy niewielkiej masie oraz energii spalin zasilających turbinę, oraz korzystniejszy przebieg momentu obrotowego w całym zakresie 
mentary loads allows a fuel reduction at high engine speeds and loads. The values of mean effective pressure reaching $2.5 \mathrm{MPa}$ and higher indicate that further research should be carried out in order to improve the presented turbocharging systems for heavy duty vehicles. The analysis and assessment of the properties of the presented solutions of multi stage and sequential turbocharging complemented by the results of own tests shows that these systems are characterized by a huge potential for further improvement of the properties of the turbocharged automotive engines. Irrespective of the configuration of the turbochargers and the switching method it is necessary to ensure the highest total efficiency of the turbocharging system. It is connected with the optimum selection of the flow elements of the compressors and turbines and determining of the characteristics of the turbocharger control which allow the adaptation of the turbocharging efficiency to a momentary engine load at an optimum division of power of the turbochargers and the compressors. Thanks to the solutions proposed by Opel and BMW it is possible to obtain the required pressures in the whole range of the usable engine speeds eliminating the lack of continuity of the turbocharging characteristics. Yet, they are characterized by large variations in the total efficiency of the turbocharging system. It is related to the changing division of power between the low and high pressure turbochargers during the switching process. This results from the changing size of the stream of exhaust flowing through the small and the large turbocharger. In order to preserve the highest efficiency of the turbocharging system, the division of power should not significantly change against the optimum value precisely determined for a given configuration. It is a typical phenomenon for serial configurations of turbochargers and has a disadvantageous effect on the overall efficiency of the engine $[1,3]$. The values of unitary fuel consumption seem to confirm this assumption. As per the manufacturer's data [28], a minimum unitary fuel consumption for the BMW engine amounts to $208 \mathrm{~g} / \mathrm{kW} \cdot \mathrm{h}$ but at the nominal power it reaches the value of $240 \mathrm{~g} / \mathrm{kW} \cdot \mathrm{h}$. These values are rather moderate as for state-of-the-art engines, comparable to the values obtained by the author in the SW 680 engine, although one must bear in mind that SW 680 represents a design of different class for entirely different purposes.

Artykut recenzowany. prędkości obrotowych. Jednocześnie lepsze dostosowanie wydajności sprężarki do chwilowego obciążenia pozwala zmniejszyć zużycie paliwa w zakresie dużych prędkości obrotowych i dużych obciążeń silnika. Osiągane znaczne wartości średniego ciśnienia użytecznego dochodzące do 2,5 $\mathrm{MPa}$ i więcej wskazują, że celowe jest prowadzenia dalszych badań w kierunku doskonalenia przedstawionych systemów doładowania z przeznaczeniem do silników pojazdów użytkowych. Analiza oraz ocena właściwości zaprezentowanych rozwiązań doładowania wielostopniowego oraz zakresowego, uzupełniona o wyniki badań własnych, wskazuje, że układy te charakteryzują się znacznym potencjałem dalszej poprawy właściwości turbodoładowanych silników samochodowych. Niezależnie od zastosowanego układu pracy turbosprężarek oraz sposobu ich przełączania konieczne jest zapewnienie jak największej sprawności całkowitej urządzenia doładowującego. Związane jest to $\mathrm{z}$ racjonalnym doborem elementów przepływowych sprężarek i turbin oraz wyznaczeniem charakterystyk sterowania pracą turbosprężarek, które umożliwią dopasowanie wydajności doładowania do chwilowego obciążenia silnika przy optymalnym podziale mocy sprężarek oraz turbin. Rozwiązania zaproponowane przez firmy Opel oraz BMW pozwalają na uzyskiwanie wymaganych ciśnień doładowania w całym zakresie użytecznych prędkości obrotowych, eliminując przy tym nieciagłość charakterystyki doładowania. Cechują się jednak znacznymi wahaniami sprawności całkowitej zespołu doładowującego. Związane jest to ze zmieniającym się, w okresie przełączania, podziałem mocy pomiędzy turbosprężarkami stopnia niskiego oraz wysokiego ciśnienia. Jest to wynikiem zmieniającej się wielkości strumienia spalin przepływających przez małą oraz dużą turbosprężarkę. Natomiast dla zachowania możliwie wysokiej sprawności urządzenia doładowującego podział mocy turbosprężarek nie powinien znacząco zmieniać się w stosunku do ściśle określonej, dla danej konfiguracji turbosprężarek, wartości optymalnej. Jest to typowe zjawisko dla szeregowego połączenia turbosprężarek i niekorzystnie wpływa na sprawność ogólną silnika $[1,3]$. Potwierdzeniem tego mogą być uzyskiwane wartości jednostkowego zużycia paliwa. Według danych producenta [28], minimalne jednostkowe zużycie paliwa silnika BMW wynosi 208 $\mathrm{g} / \mathrm{kW} \cdot \mathrm{h}$. Natomiast przy mocy znamionowej osiaga wartość 240 $\mathrm{g} / \mathrm{kW} \cdot \mathrm{h}$. Są to raczej umiarkowane wartości jak na konstrukcje silników najnowszej generacji, porównywalne z wartościami uzyskanymi przez autora w silniku SW 680 - choć trzeba mieć na uwadze, że silnik SW 680 reprezentuje konstrukcję zupełnie innej klasy o odmiennym przeznaczeniu.

\section{Nomenclature and Abbreviations/Wykaz skrótów i oznaczeń}

VTG Variable Turbine Geometry/zmienna geometria turbiny

VTT Variable Twin-Turbo/regulowane doładowanie dwustopniowe

HDI High pressure Direct Injection/wysokociśnieniowy system zasilania silnika wysokoprężnego z wtryskiem bezpośrednim

CDI Common Rail Direct (Diesel) Injection/system bezpośredniego wtrysku zasilany ze wspólnego kolektoera ciśnienia
CDTI Common Rail Diesel Turbo (Direct) Injection/system bezpośredniego wtrysku turbodoładowanego silnika o zapłonie samoczynnym zasilany ze wspólnej szyny akumulacyjnej spark-ignition engine/silnik o zapłonie iskrowym

ZS diesel engine/silnik o zaptonie samoczynnym 


\section{Bibliography/Literatura}

[1] Beineke E., Woschni G.: Rechnerische Untersuchung des Betriebverhaltens ein- und zweistufig aufgeladener mittelschnellaufender Viertaktdieselmotor. MTZ 3/1978.

[2] Bluhm K., Ganz M., Voght R.: Erfahrungen mit der Registeraufladung in einer Reiselimousine. Ref. 11, 3. Aufladetechnische Konferenz, Zürich 14-16.09.1988.

[3] Bode E.: Theoretische Untersuchungen zur zweistufigen Abgasturboaufladung, Dieselmotoren Nachrichten, 2/1969.

[4] Borila Y.G.: A sequential turbocharging method for highlyrated truck diesel engines. SAE Pap. 860074.

[5] Borila Y.G.: Sequential turbocharging helps highly-rated diesels. Automotive Engineering, Nov. 1986.

[6] Borila Y. G.: Same aspects of performance optimization of the sequentially turbocharged highly-rated truck diesel engine with turbochargers of unequal size and a pulse converter. IMechE. Pap. CIOS/1986.

[7] Bucher J.: Teillast- und dynamisches Verhalten eines Viertaktmotors mit zweistufiger Aufladung und Leistungstransfersystem. Motortechnische Zeitschrift MTZ, 10/2005.

[8] Christmann R., Schmalzl H.-P., Schmitt F., Schwarz A.: Zweistufig geregelte Aufladung für Pkw- und Nfz-Motoren. Motortechnische Zeitschrift MTZ, 1/2005.

[9] Danilecki K.: Kształtowanie charakterystyki zewnętrznej silnika trakcyjnego przy zastosowaniu systemu doładowania zakresowego. International Science Conference on Interal Combustion Engines, Kones '95. Warsaw-Poznań 1995.

[10] Danilecki K.: Wpływ doładowania zakresowego na wybrane aspekty pracy silnika. Teka Komisji Naukowo-Problemowej Motoryzacji. Konstrukcja, badania, eksploatacja, technologia pojazdów samochodowych i silników spalinowych. Polska Akademia Nauk Oddział w Krakowie. Zeszyt 15. Kraków 1998.

[11] Danilecki. K.: Analiza możliwości obniżenia zużycia paliwa silnika SW 680 z doładowaniem zakresowym. Zagadnienia Eksploatacji Maszyn. Zeszyt 3 (115). Wydawnictwo Naukowe PWN. Warszawa 1998.

[12] Danilecki. K.: Wpływ turbosprężarki drugiego zakresu na zadymienie spalin silnika SW-680 z układem doładowania zakresowego. Czasopismo Techniczne 5M/1998. Zeszyt 5. Wydawnictwo Politechniki Krakowskiej. Kraków 1998.

[13] Danilecki K.: Ocena właściwości dynamicznych silnika z doładowaniem zakresowym. Archiwum Motoryzacji. Wydawnictwo Naukowe Polskiego Towarzystwa Naukowego Motoryzacji. Nr 2/2005.

[14] Danilecki K.: Influence of criterion of controlling of turbochargers operation on fuel consumption of a vehicle engine with sequential turbo-charging. Scientific Journal of IFToMM International Federation for the Promotion of Mechanism and Machine Science. Problems of Mechanics, Nr 2(23)/2006.

\footnotetext{
Mr Krzysztof Danilecki, PhD, MEng - doctor in the Faculty of Automotive Vehicles Operation at Szczecin University of Technology.

Dr inż. Krzysztof Danilecki - adiunkt w Katedrze Eksploatacji Pojazdów Samochodowych Politechniki Szczecińskiej.

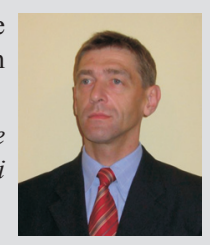

[15] Danilecki K.: Influence of algorithms of controlling of turbo-charging unit on operational properties of an engine with sequential turbo-charging. Mechanical Engineering Commitee of Polish Academy of Sciences, Institute for Sustainable Technologies - National Research Institute. Problems of Machines Operation and Maintenance. Z.1(149), Vol. 42.

[16] Delesalle J.: Ein- oder zweistufige Aufladung? Das Verfahren mit reduziertem Verdichtungsverhältnis, Teil 1: Theoretische Untersuchungen des R.V.R.-Zyklus und der zweistufigen Aufladung. Motortechnische Zeitschrift MTZ, 6/1980.

[17] Deutschman H., Wolters G.M.: Neue Verfahren zur Mitteldrucksteigerung abgasturboaufgeladener Dieselmotoren. Motortechnische Zeitschrift MTZ, 11/1983.

[18] Dinger H., Deutschmann H., Rudert W.: Forschungsarbeiten auf dem Gebiet hoher Mitteldrücke und hoher Drehzahlen auf der Basis der MTU-Motorenbaureihe 396-Teil 1. Motortechnische Zeitschrift MTZ, 11/1984.

[19] Esch E.J., Brüstle C., Tran Van K., Wagner J., Verbesserung des stationären Betriebsverhaltens von abgasturboaufgeladene Ottomotoren. Ref. 1. Aachener Koloqium: Fahrzeug und Motorentechnik, Aachen 27-29 Okt. 1987.

[20] Hetet J.F.: Modeling and simulation of internal combustion engines. Proceedings of the International Conference on Recent Advances in Mechanical \& Materials Engineering ICRAMME 05. Kuala Lumpur, Malaysia 30-31 May 2005.

[21] Jaskólski J., Mikoda P.: Sekwencyjny system doładowania typu twin-turbo. Journal of KONES Internal Combustion Engines 2005, vol. 12, 1-2.

[22] Łęgowicz J.: Doładowanie typu twin-turbo. Auto Moto Serwis, $3 / 2005$.

[23] Mysłowski J., Danilecki K.: Wpływ kompletacji turbosprężarek na parametry pracy silnika SW-680 z układem doładowania zakresowego. Teka Komisji Naukowo-Problemowej Motoryzacji. Konstrukcja, badania, eksploatacja, technologia pojazdów samochodowych i silników spalinowych. Polska Akademia Nauk Oddział w Krakowie. Zeszyt 8. Kraków 1996.

[24] Mysłowski J., Lisowski M., Danilecki K.: Ocena możliwości poprawy parametrów pracy silnika wysokoprężnego SW-680 przy zastosowaniu doładowania zakresowego. Teka Komisji Naukowo-Problemowej Motoryzacji. Konstrukcja, badania, eksploatacja, technologia pojazdów samochodowych i silników spalinowych. Polska Akademia Nauk Oddział w Krakowie. Zeszyt 8. Kraków 1996.

[25] Mysłowski J., Kotun J.: Elastyczność spalinowych silników wysokoprężnych. Prace Naukowe Politechniki Szczecińskiej nr 540. Szczecin 1998.

[26] Pflüger, F.: Die zweistufig geregelte Aufladung (R2S) - ein neues Aufladesystem für Nfz-Motoren. Motortechnische Zeitschrift MTZ, 7-8/1998.

[27] Syassen O.: Zukunftaussichten der zweistufigen Aufladung für Zwei- und Viertakt-Großdieselmotoren. MTZ, 11/1976.

[28] Steinparzer F., Kratochwill H., Mattes W., Stütz W.: Der neue BMW Sechszylinder-Dieselmotor mit Stufenaufladung . Motortechnische Zeitschrift MTZ, 5/2005.

[29] Wisłocki K.: Systemy doładowania szybkoobrotowych silników spalinowych. WKiŁ. Warszawa 1991.

[30] www.bmw.com

[31] www.peugeot.com

[32] www3.mercedes-benz.com 